\title{
Korean Adoptee Auto-Ethnography: Refashioning Self, Family and Finding Community
}

Through exploring my identity as an adopted Korean. I hope to speak to others with similar experience and share it with others. I have never seen a film or video by/ or about adopted Koreans. We don 't have a unified community. We are spread out here in Minneapolis. mostly in suburbs. adopted by affluent white families. The isolation. alienation. self-hatred and fear that are ever present in our lives is mind-boggling. Creating personal work serves as a tool for self-transformation.

Me-KAndo (Me-K. Ahn) (1994)

This is a photograph that was taken of me to give to my new parents. My American mother gave it to me years later. but it wasn't enough. so I went back to Korea. in a way to make my own documents of memories that exist now only in my mind.

Great Girl (1993)

Guard against behaviors that would betray biology. A sense of natural family and history is available in daydream and fantasy. I repair the broken narrative by dreaming it along.

Looking for Wendy (1997)

Four years after Korean adoptee-filmmaker Me-K. Ahn commented on the lack of any "unified community" among Korean adoptees, she organized "Evenstill." a showcase of film and video works by Korean adoptees and Korean "kyopos"(second-generation transnationals), at the Minneapolis College of Art and Design. Featuring 19 films and videos. eight of which were produced by or about Korean adoptees. "Evenstill" is one of a range of social practices. cultural forms. and sites of communal action that have been organized and directed by adult adoptees over the past few years. Through these activities, a public face of "Korean adopteeness" is being constructed. registering a grow-

\section{ELEANA Kim}

ing presence and self-conscious building of " community" among Korean-born people adopted by families in the West.

Great Girl (Theiler 1993) and living in halftones (Ahn 1994) were early examples of what is now a remarkable number of films and videos by adoptees who have returned to Korea to make their "own documents of memories." Around a dozen of these works have been shown nationally and internationally in film and video festivals. at screenings specilically targeted for other adopted Koreans and their families. in showcases of adoptee creative work in Korca. and more recently. on U.S. public television. While the work is diverse, similar themes and common stylistic choices emerge in these attempts to address questions of memory. history and the search for self. These works take the indeterminacy of identity as a central premise. and like Michael Fischer" s "post-modern arts of memory" (1986) show that "ethnicity" (or. better. "identity") is "something reinvented and reinterpreted in each generation by each individual and that it is often something quite puzzling to the individual. something over which he or she licks control" (195).'

In this essay. I refer to this body of work as "Korean adoptee auto-ethnography" following Catherine Russell 's usage of that term (1999: 275 ff.). According to Russell. "Autobiography becomes ethnographic at the point where the film-or videomaker understands his or her personal history to be implicated in larger social formations and historical processes" (276). The films and videos of Korean adoptees seek to answ er questions about identity and selfhood. family and history. foregrounding the ambiguity of ethnic. biological and social relatedness. This paper examines six Korean adoptee auto-ethnographies, examining each as a "stiging of subjectivity" (Russell: 276), and as one of a growing number of expressive practices animated by 
the core experience of being a transracially adopted Korein Americiin.

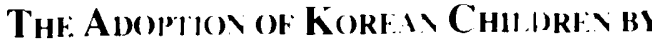

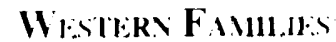

South Korea has been a major source of children for families in developed countries since 1955. Initially. war orphans-many of them bi-racial children of U.S. and UN military soldiers and Korean women-were adopted for humanitarian reasons, largely spearheaded by the late Harry Holt. a farmer from Oregon. who was motivated to salve the poor children he saw on a World Vision television report. A legendary figure in Korean adoptee history. he and his wife. Bertha, first started the stream of children from Korea to the U.S. in 1955 when they adopted eight GI babies. Largely through their efforts. both the Korean and the United States governments hastily passed legislation to facilitate the rescue of these children (sec Sarri et al. 1998). The Holts soon established Holt Adoption Agency (now Holt International Children's Services) which continues to be the leading agency for transnational adoption today. Following the first wave of biracial children came fullblood Korean orphans. relinquished in large part due to extreme poverty. a lack of social service options. and a staunchly patrilineal. "Confucian" society which places primal importance on consanguineal relations. especially on the status that comes with hearing sons. ${ }^{3}$ According to Alstein and Simon (1991). Korea allowed "almost unrestricted adoption" of orphaned and abandoned children from the 1950) through the 1970)s.

Whereas the women who relinquished their children in the 196()s and 70)s tended to be poor factory workers, by the 1980s. as Korea' s economic boom took off. unmarried college-age women were giving up their babies. Today. it has been reported that a trend in teen pregnancies hals supported the supply of adoptable babies. ${ }^{+}$No doubt. factors such as Korea's rapid industrialization. unstable economic development. patriarchal attitudes about women's sexuality. residual gender ideologies in contradiction with liberal sexual practices, and the recent I.MF crisis serve to perpetuate the social conditions which contribute to the abandonment or relinquishment of children in Korea. Between 19.55 and 1998. over 197.()() Korcan children were adopted in South Korea and abroad. with around 140.(0)() having been sent overseas." Approximately $[0(0.0)(0)$ of those were adopted by American parents. and the remainder by Europeans. In the United States. Korean adoption accounted for over half of the total international adoptions during the 1980s and early 1990s. At its peak in 1986. 6. I88 Korean children were adopted in the U.S.. constituting 62 percent of the total. In 1989. with most countries sending less than $1 / 10$ of one percent of live births abroad. Korea was sending I percent of live births (Kane 1993: 336). a rate that earned it the reputation of being "the world"s leading exporter of children."

North Korea had already criticized the South Korean government for its liberal adoption policies in the late 1970s. and the government subsequently took steps to dampen the flow. 6 Then. when South Korea achieved international recognition and honor as the host of the 1988 Summer Olympics in Seoul. it also received negative scrutiny from the American press for exporting its "greatest natural resource," its children. ${ }^{7}$ Reportedly bringing in $\$ 15$ to 2() million per year. adoption in Korea had become a business and a cost-effective way of dealing with social welfare problems (Herrmann and Kasper 1992: 50: Sarri et al. 1998). Due to growing ignominy in the eyes of the international community. the government soon announced a plan to gradually phase out adoption. implementing a quota system to reduce the number of children sent abroad by three to five percent a year. In addition. state policies in the early 199()s encouraged domestic adoptions through tax incentives and family benefits and gave preference to foreign couples willing to adopt bi-racial. or "special needs" children.

Despite a reduction in foreign adoptions. over the past five years Korea has continued to rank third in the world-after Russia and China-in the number of children adopted by Americans annually." An elevenyear decline in transnational Korean adoption was reversed with the sudden economic crisis of 1998. which caused a concomitant crisis of overflowing orphanages. In 1996 approximately 5.000 children were placed in state care. and that figure was projected to be double in 1998. leading the Ministry of Health and Welfare to recently announce that it "has no choice but to make changes to recent policy which sought to restrict the number of children adopted overseas" (Kim 1999). More recently. there are reports of an increase in domestic adoptions which have been on an unprecedented increase since 1995. with 1.726 adoptions by Koreans in 1999 (Soh 2000). and international pressure 
for Korea to ratify the Hague Convention on International Adoption would effectively do away with the quota system (Kim 2000): Park 2000).

\section{Ovfrseas Adopted Korfins (OAKs)"}

The isolation and alienation of being a Korean adoptee expressed by Me-K. Ahn in 1994 has been echoed by other adult adoptees who have recently come into contact with each other through new communication and media technologies and other sites of collective articulation." This isolation is a by-product of their common life histories-raised by mostly white parents in homogeneously white suburbs, scattered across the U.S. and in remote towns in Wentern Europe." The networks of association encouraged by adoption agencies today did not exist for many who were adopted in the 1950s. 60s and 70s. Adoptees were by and large encouraged to become "American" - often meaning the wholesale embrace of a new identity. family and history. '2 For many. their "arrival day" - the day they were picked up at the airport by their American parents and began being called by their "American" namebecame as significant as their birthdays. ${ }^{13}$ Even if the possibility for exposure to Korean culture was available. many adoptees admit that they were resistant to being identified as "other." as Asian or Korean. In her film. Crossing Chasms (1998). Jenniter Arndt describes her feelings about going to Korean culture camp in junior high school: "I resented my Asian identity. and going to camp reinforced my Koreanness when 1 wanted to be quote-unquote white."

In 1976 Holt International Children's Services began the Holt Motherland Tour. an annual event for older adoptees to return to the country of their birth. and in 1983. Holt Korean Culture Camp was established to give adoptees the opportunity to learn about Korean culture as children and adolescents (McGinnis et al. 1999). Now. an increasing number of adopted Koreans are returning to Korea through Motherland Tours and also independently. They go there to travel. work. to locate their birth families and to experience "Korea." Arndt. like Ahn. grew up in Minnesota, which has one of the largest populations of adopted Koreans in the nation, yet she met more adoptees in Korea than she had ever met in the United States. ${ }^{15}$ This relationship to
Korea and the physical return to a symbolic place of origins and memory. real or imagined. in the subject of the films and videom produced hy adoptees.

For many of them. having arrived before the rise of the American multiculturalist ethos. pressures to assimilate led to the erasure of conflict and the repression of dissonance within a familialist ideolog:-registering a desire to transcend racial difference in favor of achieving the ideal of the "American family. " Having come of age now. many are excavating their own pasts. and critiquing the assimilationist models. both socially imposed and psychologically internalized. to consider their own unique position from a different perspective and to ask questions about kinship. social relations. biological ties. and "family" ideology. Against the available discourses provided by Korean. American. and Korean American communities. they are actively and self-consciously exercising a Korean adoptee "voice." in the process of naming and constituting a "fourth culture" (Stock 1999). Hollee McGinnis. a strong adoption advocate and kirean adoptee community organizer. has written about the "success stories" of adoptees. their exceptionalism and achievements: "Buoyed by a rising national Asian and Korean American identity. these young professionals are striving to define their own unique individuality." (McGinnis et al. 1999: 4). ${ }^{17}$

As one modality of the claboration of these transnational subjects. Korean adoptee auto-ethnographies exist in the context of a range of sites and forms for the expression of "Korean adopteeness." Since the carly 199()s. at least a dozen adult adoptee organizations and support groups have sprung up worldwide-in Europe. Australia. the U.S. and Korea. Along with numerous listserves. Web sites. newsletters. magazines. and books. these groups constitute a growing sense of "discursive consciousness." revolving around shared historical origins and common experiences with assimilation. racism. identity. and dual kimship. A critical tipping point was reached in 1999 - three major. international events in I9y9-that stggests that a preliminary sketch of a public face for transnational. Korean adoptec identity is developing aclearer outline. Adoptees of Korean descent are producing and managing a growing sense of collectivity ${ }^{\prime \prime}$ from the at ailable cultural and ethnic categories. They are performing their own

Eleana Kim (M.A. Anthropology/Culture and Media. NYU) is a Ph.D. candidate in Anthropology at New York University. 
form of cultural work. on the borderlands "beyond culture" (Ferguson and Gupta 1992), and as serting their position in a global "ethnoscape" (Appadurai 1996) constructed out of the existing discourses of Korean diaspora and transnationality.

\section{HISTORY AND MrIIORY}

In the past two decades. "memory" has become a key trope for many artists of color and "communities of the disenfranchised" (Bordowitz 1996: 176)-groups historically excluded from dominant accounts of Western culture. history. and nation. In many of these works. historical revisions and refashionings of selthood intertwine. such that personal memory achieves the status of "a history." and in doing so. reveals the gaps and elisions in "official" versions of historical truth. Film has proven to be a powertul means by which these alternative histories are constructed and disseminated. ${ }^{19}$

For transnational Korean adoptees who left Korea as children. the problem of memory is one effect of their displacement and dislocation from a "real" biological family. Me-K. Ahn and Kim Su Theiler's work can be read as compensatory efforts to locate a space of nostalgia within a field of uncertain or occluded memories. These films are. in part. a process of recovered memory, reconstructing a sense of "family" through a re-negotiation of the institutionalized and naturalized definition of family as biologically conditioned (cf. Bourdieu 1998). Normative jdeals of kinship-the primacy given to blood and genealogy in both American and Korean cultures-are challenged by these adoptees' confrontations with their pasts and with their own assumptions and ingrained expectations about kin relations (cf. Schneider 1968). In these works, kinship stands as a desperate and vital act of recognition. whether it be out of curiosity. a desire to see someone who shares physical characteristics, to fill an emotional void. or to achieve some kind of resolution.

The dual nature of adoptee memory as represented through film and video shares a sense of distance and mediation with what Marianne Hirsch calls "postmemory" (1997). As she theorizes it. postmemory is "distinguished from memory by generational distance and from history by deep personal connection... its connection to its object or its source is mediated not through recollection but through an imaginative investment and creation..." (22). She notes also that postmemory "characterizes the experience of those who grow up dominated by narratives that preceded their birth, whose own belated stories are evacuated by the stories of the previous generation shaped by traumatic events that can be neither understood nor recreated " (22).

Although adoptees have an actual biological and historical connection to Korea. for many of them the memory of their lives there have faded or been completely eradicated over time, by distance, and the process of acculturation. ${ }^{21}$ Many of these videos reveal the deep sense of alienation that this process of forgetting has produced. in the sense that the only thing remembered is the process of forgetting itself. leaving the trace of memory which. never fully forgotten. cannot, at the same time, be fully remembered. Deann Borshay recalls her desperate attempts as a newly adopted child to fight the process of forgetting and to retain a singular memory of her home in Korea: "It was getting more and more difficult to remember how to get home. I remember closing my eyes and saying, ok. don't forget. but the last memory of Korea was starting to fade.... I forgot everything. I forgot how to speak Korean: I forgot any memory of ever having had a family. and I even forgot my real name" (First Person Plural 2000).

\section{KoREAN ADOPTHF: AITO-F.THNOGRAPHY"1}

This paper is a preliminary attempt to discuss the role of film and video in the construction of Korean adoptee identity. As an emergent form. "Korean adoptee auto-ethnography." considered as a "type," like that of "Korean adoptee identity" itself. is clearly an ideational fiction. I am wary of attempts to theorize a distinctive "style" (cf. Naficy 1997). a reduction which would be overly suggestive of a self-limiting culturalist position. Rather, this paper will try to show that Korean adoptee films are performances of the search for identity. and seeks to approach "Korean adoptee-ness" as historical. contingent. emergent. and particular. At the same time. however. it is remarkable that. despite their relative isolation from other adoptees. each of these filmmakers selected very similar tropes and themes to express his/her experiences of being adopted..$^{22}$ While this might suggest the existence of a Korean adoptee "structure of feeling" (Willjams 1977), or even the emergence of something like a "genre." I am 


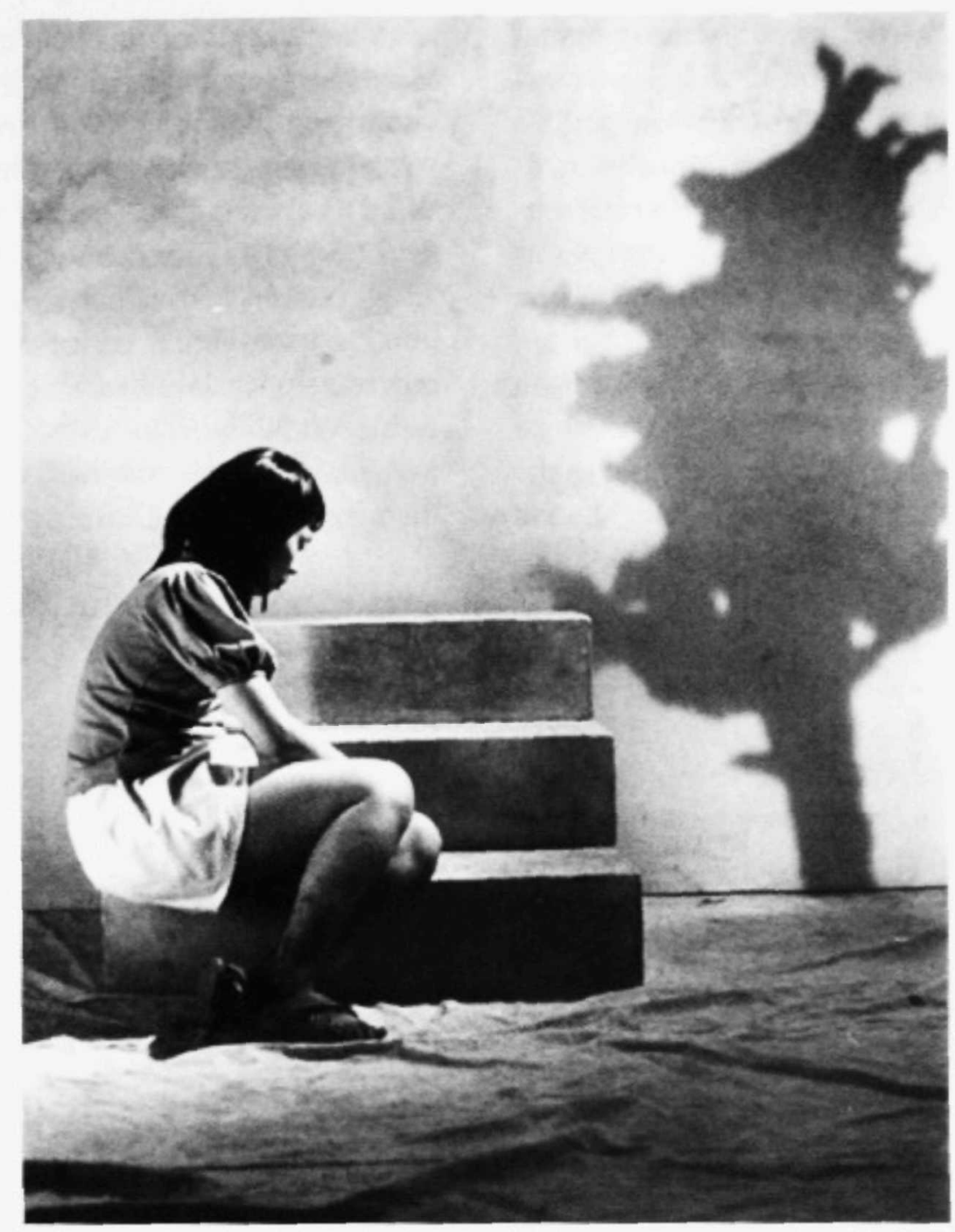

From Kim Su Theiler's Great Girl. Courtesy: Women Make Movies

cautious about making such predictive claims, and have. rather, more modest goals of outlining what appears to be a growing self-awareness among adopted Koreans. both individually and collectively. These films and videos are part of that self-awareness, socially produced in a specific field of cultural production (Bourdieu 1993). ${ }^{23}$ These works are about memory and history. and stand as interventions and counternarratives to "official" versions of Korean or American culture from which, until recently, adoptees have been excluded. Each work is a kind "journey of the self" (Russell 1999: 275) and each finds ways of representing a memory that is at once internal and distant. locked in childhood and located in the elsewhere of "Korea" and Korean culture.

In the past two years, these films and videos have been shown at various film and video festivals. on public television and at Korean adoptee organized events such as the first Korean American. Adoptee, Adoptive Family Network (KAAN) national conference in Los Angeles in July 1999. Each of the filmmakers has been affiliated with some form of arts institution, from local organizations, to university film schools, to national public television foundations. Funded in large part by non-profit arts foundations, the works have received numerous awards, and in many cases, the work 's first recognition was at festivals outside of the Korean adoptee network, only later being targeted for a specific audience of other Korean adoptees. ${ }^{24}$

These films and videos are explorations of a destabilized subjectivity which often symbolically of mimetically incorporate the search process in Korea to broach questions of origins, identity, and truth. Like other forms of "narrowcast" media among activint. diasporic, exile or transnational groups (Juhase 1995: 
Naficy 1997: Schcin 2(0)(0). this work has the potential to be a mode of community-building. and also stands as a necessary counterdiscourse to mainstream media's underrepresentation of Korean adoptees (not to mention Korean Americans). It also stands as an intervention into stereotypic depictions of (white) adoptees as dysfunctional. troubled or deviant. These works like their makers. exist at the convergence ${ }^{25}$ of established discursive formations and newly emerging ones. from which they articulate a Korean American and adoptee identity, actively negotiating a space in relation to the existing Korean American community. the Korean diaspora. and white American (adoptive) communities in the United States.

Works like Me-K. Ahn's living in half tones and Kim Su Theiler's Great Girl fall into a kind of experimental artistic video genre that Lalura Marks (20)(0) has dubbed "intercultural cinema." A cinematic practice of formal experimentation and epistemological questioning. Marks"s intercultural cinema is distinguished by a diasporic consciousness which attempts "to represent the experience of living between two or more cultural regimes of knowledge. or living as a minority in the white Euro-American West" (I). It is produced by people "who share the political issues of displacement and hybridity" (2). ${ }^{26}$ and for whom memory takes the form of embodied. non-discursive knowledge. Marks periodizes what she calls "intercultural cinema" as emerging between 1985 and 1995. in the context of multiculturalist discourses, the availability of funding for noncommercial film and video art. and "postmodernist" interventions into modernist "master narratives" (2). ${ }^{27}$

Marks"s interest in these works overlaps with the work that Michael Renov described in 1995 as the "new subjectivities" of documentary - "the growing prominence of work by women and men of diverse cultural backgrounds in which the representation of the historical world is inextricably bound up with self-inscription." He notes a "more personalist perspective in which the maker"s stake and commitment to the subject matter [is] foregrounded." And Catherine Russell"s Experimental Ethnegraphy (1999) ends with a discussion of "auto-ethnography:" "a vehicle and a strategy for challenging imposed forms of identity and exploring the discursive possibilities of inauthentic subjectivities" (276). Korean adoptee auto-ethnographies share many of the tropes that Russell discusses. including the diaristic. confessional mode. and the filmmaker's reconstruction of memory through interviews with older relatives (parents and grandparents): "One gets the sense that the filmmaker has no memory and is salvaging his or her own past through the recording of family memory" (276).

The films and videos by Korean Adoptees all fall into the "post-verite" period described by Renov. Each one is a self-inscription. an enactment of subjectivity. a "becoming" of identity through the filmmaking process. Like the work of indigenous mediamakers theorized by Faye Ginsburg (1991). Korean adoptee autoethnography might also be described as "ethnographic media." in being "about the processes of identity construction" (105: emphasis in original). Although the films of these U.S.-raised Korean adoptees follow an arguably more American orientation-by organizing their modes of address around a singular (heroic) individual. rather than on the collective subject more commonly represented in indigenous mediaKorean adoptee autoethnography shares in a process which attempts "to mediate. literally, historically produced social ruptures and to help construct identities that link past and present in ways appropriate to contemporary conditions" (Ginsburg 1991: 94).

Some rewrite a past by excavating memory and history. others are looking for new ways of expressing their "hybrid" identity, reconsidering the choices they have. the ones that were made for them. and the ones they can now make for themselves. ${ }^{28}$ Indeed. for the personal documentarists, the theme of self-knowledge and maturing into adulthood is common. The videos document a process of catharsis. in which they attempt to reconcile fantasy and reality. returning to a stronger sense of who they are. a recognition of the complexity of relationships and a greater appreciation for their "real" or "true" families in the U.S. As life histories. they are attempts to produce coherence. to "repair the broken narrative by dreaming it along. " in the words of Kimberly SaRee Tomes. As representations of life experience. they foreground the indeterminate dialectic between biology and culture. reconciling the self with unanswerable questions and conditional answers.

At the same time. there are distinct differences among the works. Kim Su Theiler's Great Girl (1993). Me-K. Ahn's living in halftones (1994) and Kimberly SaRee Tomes's Looking for W'ndy (1997) are much more experimental in their form than the work of 
Jennifer Arndt, Nathan Adolfson and Deann Borshay. The latter present subjective, confessional voiceovers and direct address with verite-style documentary footage, more in keeping with what Russell describes as "auto-ethnography." In all of them, the "other" is "Korea" in all its valences - as memory, place, "culture," as self, and family.

Looking for Wendy is more playful than most of the films under consideration. but Kimberly SaRee Tomes articulates many of the themes of curiosity. desire. and lack that appear in the other films. Unlike the other tilmmak.

ers, however. she focuses on her relationship with her adoptive father. and her poetic voiceoverexplores moreexplicitly the process of writing the self: "Sometimes in my mind I visit overseas and select the seeds that I carry back with $m e$ and from there I can see parts of you. Fragments combine and recreate, selecting information that is there, both narratives, and find, cre-

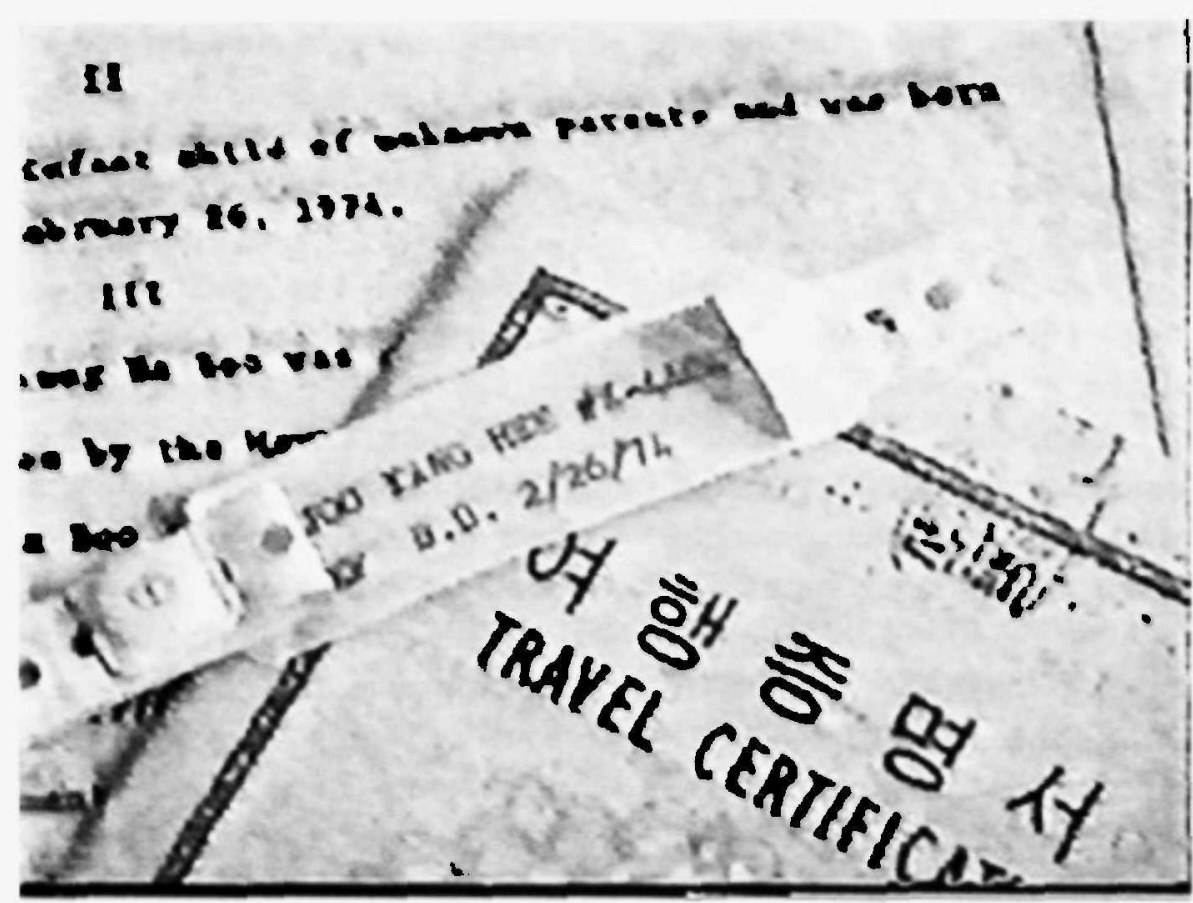

Jennifer Ardnt's immigration and adoption documents. From Crossing Chasms. Courtesy: Jennifer Ardnt. in the context of the production of an adoptee's subjectivity and her desire to have incontrovertible know ledge about genealogical family and heredity:

Something to do with generations, something to do with heredity and environment, and placement and being displaced and uprooted, and. .. oh. how unexpected phenotypes emerge depending on the location.....If a plant is bred in a specific region. is relocated to a specific environment. unexpected phenotypes emerge that were unknown, unanticipated in its genetic makeup.

The other adoptee-filmmakers document an actual, rather than imagined return to the "motherland." an ambivalent and/ or complicated relationship to Korea and/or to their birth families. Yet by abstracting her situation and displacing it into "science." Tomes, like the other adopteefilmmakers, constructs Korea as an "elsewhere," and Korean parents and Korean culture as a mysterious part of his/herself.

Passing Through (Nathan Adoltson 1999), First Person Plural (Deann Borshay 2000), and Searching for Go-Hyang (Tammy Tolle/ Chu Dong Soo 1998) each document the film-maker's search and reunion with biological family in Korea. Crossing Chasms (Jennifer Arndt 1998) is also partly a search and reunion narrative, but Arndt was unsuccessful in finding her biological parents. What she presents instead is an ethnographic look at Korean adoptees in Korea, motivated by her own feelings and experiences of being swept into a search process she had not intencled to pursue. After placing an advertisement in a new spaper. a woman comes forward who believes that Jennifer is 
her first daughter, given away because the relationship with Jennifer's father was not parentally-sanctioned. Experiencing the confused enotions of wondering if this woman is her biological mother. Arndt explores what it means to be related to someone. When the DNA tests reveal that they are not. in fict. blood relations, she expresses deep disappointment, yet also a sense that what she has not gained in family she has gained in selfknowledge: "I just wanted that mirror-inage. I wanted to know and understand myself better-what I realize now is that I do know myself better."

For these search and reunion documentaries, the problem of narrative coherence is solved through the use of the "diary" form. The narrative follows a conventional arc in which the protagonist leaves home. goes abroad and experiences a major life change. and returns with a new sense of self. Adolfson calls his film a "personal diary documentary." and his wry. selfconscious voiceover provides the backbone for the images and interviews which compose his film. Arndt and Borshay solve the problem of narrative coherence with combinations of voiceover and direct address. On the border between documentation and documentary. the diary format and direct address are often used to convey a sense of authenticity and immediacy, collapsing distance and displacing "objective realism" for subjective representation. In the catse of Borshay. it is difficult not to take her raw and emotional delivery. recorded in hotel rooms during her stay in Korea. as "authentic" displays of her psychological states.

In contrast to Borshay's earnest and bedraggled face appearing in close-up. there is Arndt's very stylized use of direct address. in which she sits on a stool in front of a blue curtain in what seems to be a photography studio. She speaks to the camera, appearing very well-groomed. and never very emotional. with a delivery that is highly scripted and poised. Ultimately. however. she is no less performative than Borshay. In both. the expression of emotion play's upon a voyeuristic desire to see the "real" pain of being an adoptee. Ardnt. however. never cries for the camera. Rather. the sense of immediacy and "presentness" of Borshay "s personal testimony is in contrast to Ardnt s very controlled recapitulation of an experience she seems to have already worked through.

\section{The ARCHIV F}

For adoptees. early photos from the adoption agency or the orphanage stand as important. if ambiguous, documents of memory. In Korean adoptee autoethnography. documents and photos figure prominently. as they do in other modalities of adoptee selfrepresentation. "Before" and "after" photos often frame. pictorially. a narrative of their lives, a departure and a destination. mapping the disjunction from one location and name-one identity. or one set of possible identities-to another ${ }^{311}$ Written, "official" documentation and photographs are exhibited as visible evidence of a pre-adoption past. artifacts pointing to a place and time beyond language. lost in memory too deep and too distant to be easily retrieved. The indexical quality of the photograph. and the "truth" value of the paper document stand as semiotically vacant. yet ontologically powerful, evidentiary objects.

Great Girl (1993) is an imagistic recreation of the filmmaker's return to Korea to seek information about the orphanage where she stayed and about her birthmother. It begins with an adoption registration document with a passport size photo of the filmmaker as a little girl and ends with a photograph of her outside the orphanage, the one taken of her to show to her American parents (see epigraph). Fragments of memory are recreated imagistically. juxtaposed with an aurallydistorted narration (echoed, doubled, or delayed) which recounts her experiences of searching in Korea. These stories are layered with recovered memories. represented through theatrically-stylized dramatizations, both marked by disjunctions between memory and place.

The film begins with a sequence of a young Asian woman maladroitly performing a conventional Korean domestic chore: slicing and coring an apple and arranging it on a plate. The audio track records the filmmaker trying to locate information about the orphanage with the help of a translator. She learns that the orphanage no longer exists, rather, there is a taxi depot in its place. When she asks for a copy of the old map which shows where the orphanage once was. her translator replies. "But that does not exist, so not important." The filmmaker says. "Yeah. but it exists in my mind, you know-it's the only documentation." She gets help from a newspaper reporter who finds the gardener at the orphanage she thinks she came from. ${ }^{32}$ On the way to 
meeting a woman who claims to be her mother. she is able to recognize specific locations. and things exist where she knew they would: "I pointed to where there should've been a noodle shop and about where the beauty shop should be. And yes. there was a noodle shop where I said and a bealuty parlor up to the left."

A childhood accident with scissors left a scar near the filmmaker's eye and it stands as a mark of identification which brings her closer to finding some verification of her past. Yet a woman who claims to be her mother. who even says that her child had a scar in the same place, also from playing with scissors. shows the filmmaker photographs of her child, and they bear no resemblance. Each moment promises to be a sign of "truth." where memory and reality make a fit. yet each is undermined by another disjunction. ${ }^{33}$

Me-K. Ahn's living in halfiones ${ }^{34}$ shows a black and white photograph from her orphanage with "Baik Me Kyung \#6.316" written on it. The voiceover of an adoption agent loops: "You were found. they say. somewhere in the city." Nothing concrete is known of her origins: the agent can "t even say who "they" is. In living in halftomes, this photo appears like a talisman. and for Kim Su Theiler. the image her American mother gave back to her is "not enough." Yet for each filmmaker. the photograph is the central image around which the imaginative creation and recreations of her past are organized.

Ahn has no memories of Korea. but her video stands a recreated memory-archive, juxtaposing images from Korea- of orphanage children. street scenes. repeated images of a pouch. flowers. a child's angry face-with the voice of the adoption worker being interviewed by Me-K. about her time in the orphanage. She is told in a matter-of-fact way that she wasn 't given much physical affection because of the trauma that would result if she got too attached to anyone at the orphanage. This information is accompanied by text: "The shocking news even came from a white guy wondering why a Japanese immigrant would want to adopt Korean babies. I was left with horrid thoughts that I didn't belong in yet another way."

Nathan Adolfson "s papers are exhibited in Passing Through as signs of his former identity as Choe Ji Man: "I lived this Choe Ji Man until I was three. when my father died." Jennifer Ardnt, who was left at the entrance to an orphanage as a one-month old infiant. begins her video with photos of her parent and adoptive siblings. A childlike girl's voice introduces the members of her family, with their names. and the date and location of their births. When her turn comes up. she shows images of adoption and immigration papers, and her adoption agency photo saying. "I don t know exalclly when I was born. but I was adopted from Pusan. Korea in 1974 when I was a baby. The people at Holt gave me a name and some other number. See. on this photo: K4+()t. I had fat cheeks." As Ardnt does. Adolfson and Borshay also include family snapshots (and in Borshay"s (alse. home movies), as another form of proof. that their childhood experiences fit the "typical. all-Anerican stereotype" (Ardnt. Crossing Chasms).

Yet documents and photographs, while they are officially signified as "truth" or "cvidence." can also be falsified. or misread. Deann Borshay"s First Person Plural documents her reunion with her biological parents after her discovery that her adoption had been a cane of mistaken identity. Adopted in 1966 at the age of nine. she was believed to be Cha Jung Hee, an orphaned girl that the Borshays decided to ad'pl after they had grown attached to the idea of hes from exchanging photographs and sending money and letters to her orphanage in Korea. Haunted by memories of Korea and of her family life there. Deann. when she is old enough. tries to tell her adoptive mother that she is not who they think she is, and that she has a family in Korea. Her worries are dispelled as "bad dreams." and Deann's mother shows her the adoption papers as evidence that her parents are both dead. and that her name is, in fact. Cha Jung Hee. Not until she is an adult. however, does she uncover the truth. when she finds two different photographs of young girls. both with the name Cha Jung Hee written on the back: "The problem was. only one of them looked like me."

She writes to the orphanage and receives a letter from her biological brother that tells her that she does. in actuality, have a mother and four siblings in Korea. and that her real name is Kang Ok Jin. The real Chal Jung Hee, all set to be sent overseats to her new family. Was retrieved from the orphanage by her father at the last moment. and Deann/Kang Ok Jin was sent in her scad. The adoption papers were falsificd. unbeknownst to the Borshays. and despite the clear differences in the photographs of the two different girls, the Borshays didn't notice, or chose not to notice. When she confronts her parents and siblings with this informaltion in the video. none of them seems to be bothered by the fiact 


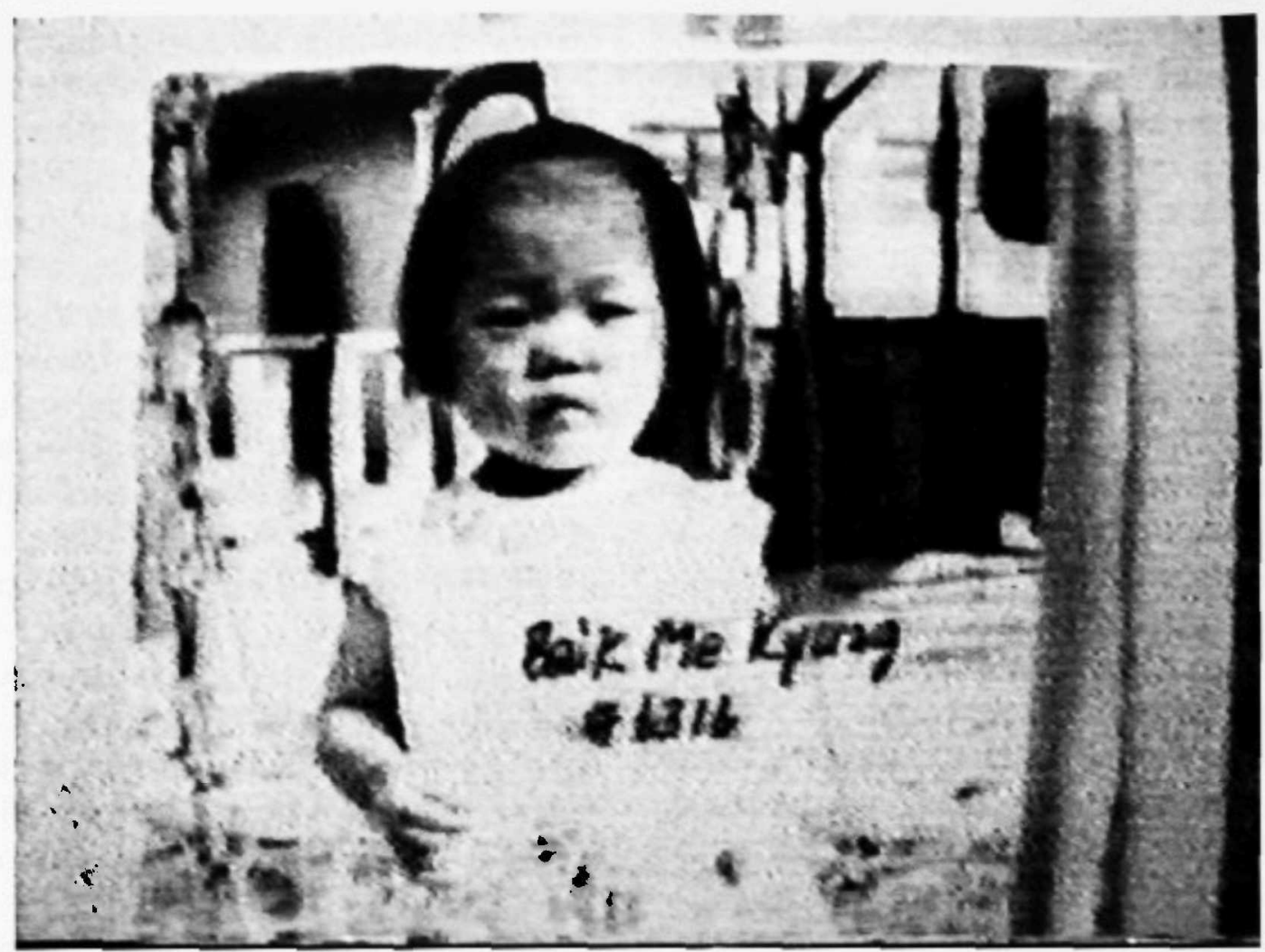

"You were found, they say, somewhere in the city." From living in halftones. Courtesy: Me-K.Ahn.

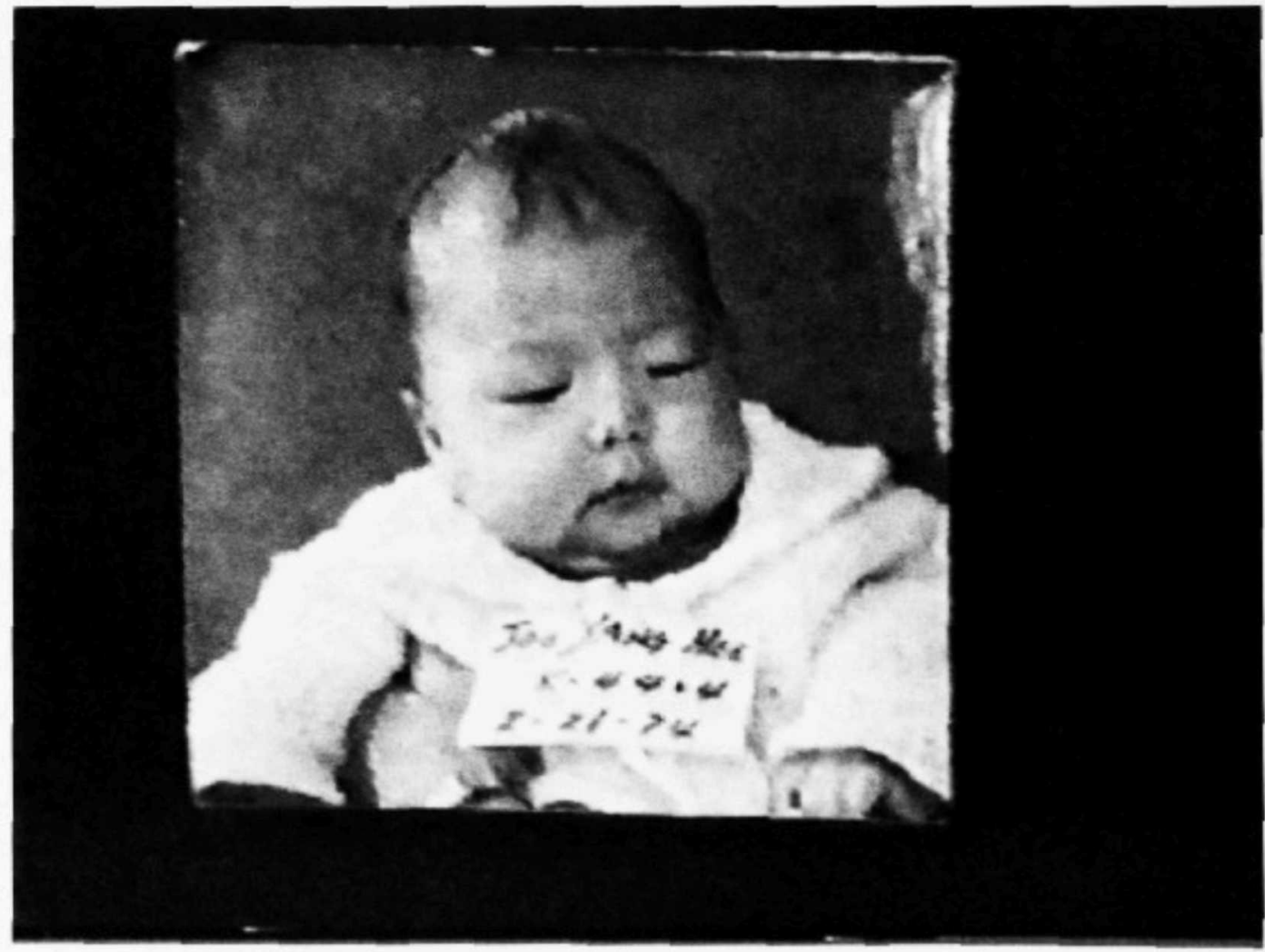

"The people at Holt gave me a name and some other number. "From Crossing Chasms. Courtesy: Jennifer Ardnt. 


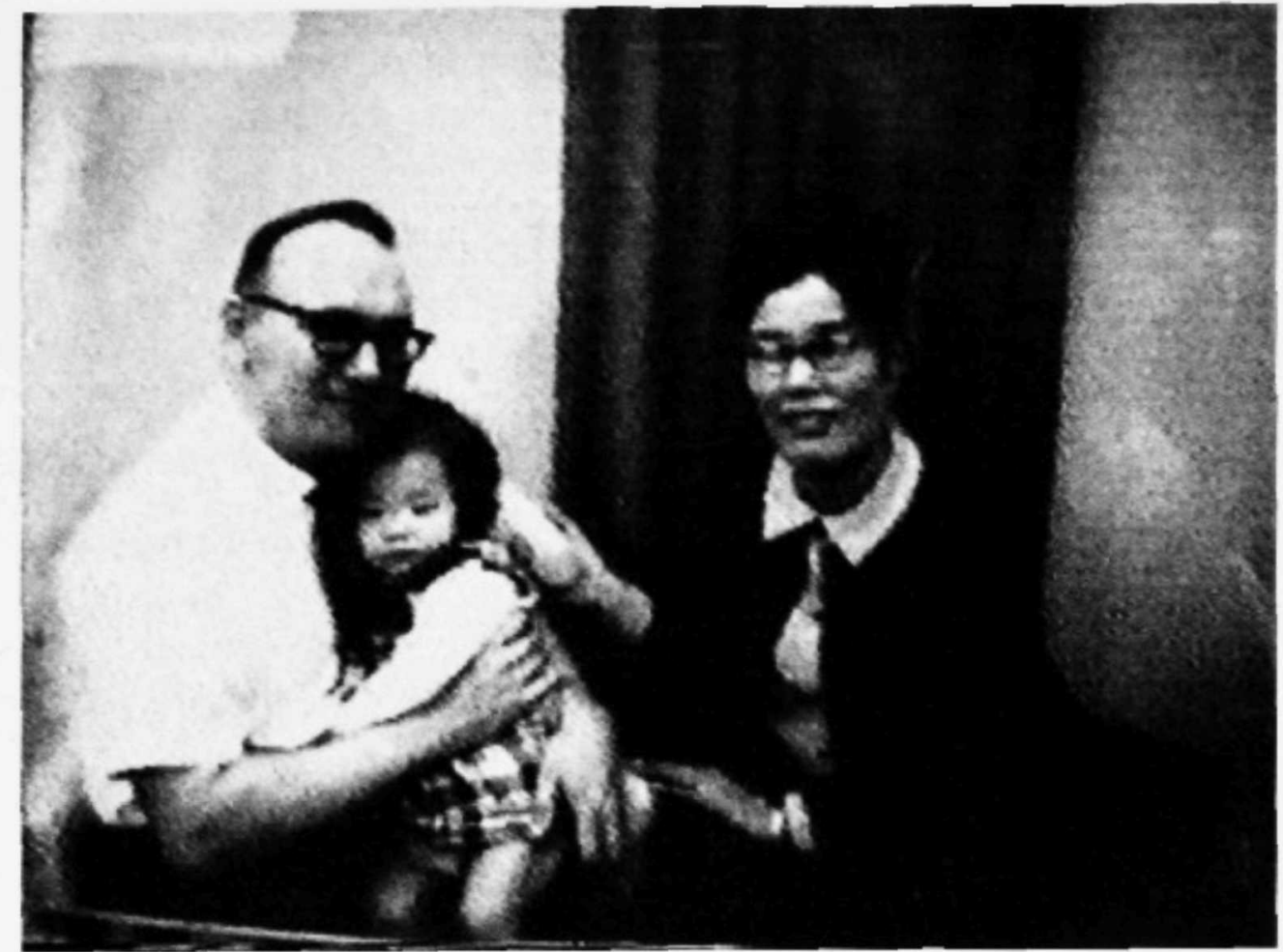

Karen Me Kyung Muckenhirn and her adoptive parents. From living in halftones.

Courtesy:Me-K.Ahn.

that she is someone other than they thought she was. She gets reactions such as: "Kang what?" "Oh, you're just Cha Jung Hee to us." "You're just Deann." Her adoptive mother says. "I didn't care that they had switched a child on us. You couldn't be loved any more and just because suddenly you weren't Cha Jung Hee. you were Ok Jin Kang or whatever, didn't matter to me, you were Deann and you were mine."

\section{Visinit Evinence.}

Pre-adoption photographs stand in for the irretrievable past. The knowledge that they convey must be (re)constructed, imagined and lived with as partial and indeterminate. Against these images cut of from experience and memory there are the photos and home movies shot by the adoptees' American families. These figure prominently in the work of Adolfson, Borshay and Ardnt. They encode what Marianne Hirsch calls the "familial gaze," framing the adoptee in the "typical American family." As Nathan Adolfson says in Passing Through. "Growing up, I thought we were the perfect American family...till I realized I was adopted." In another part of the video, his sister tells him. "I understand that you're Asian. but you're also Natham Adolfson. a part of the Adolfson family." As she emphasizes his being part of a larger kin network, we see a close-up of a photograph showing Nathan in one corner. and when the shot gradually pulls back we see him as one individual in a large family portrait photo of at least thirty others who identify as the "Adolfson family."

These videos demonstrate through photographs and interviews with parents and siblings the extent to which the filmmaker was naturalized into his/her American family, as one of "us." The uneasy contradictions of ethnicity and race are aptly illustrated by an artistic photograph taken of a young Deann, dressed in a sailor's suit, with a Chinese parasol balanced on one shoulder. framing her smiling face. Deann Borshay's brother, who, in the beginning of the documentary is shown touting America as "superior to every other place in the world," later in the video says that he's never thought of Deann as any different from his biological sister, that she doesn"t have "the family eyer," but she's "got the family smile." Likewise. Nathan Adolfson's sister says, "I never thought of you as different. as being anything other than my brother. And the only reason I knew you were Korean was. one of my friends would say things. I remember this asshole. he was drunk and was at our house and was 


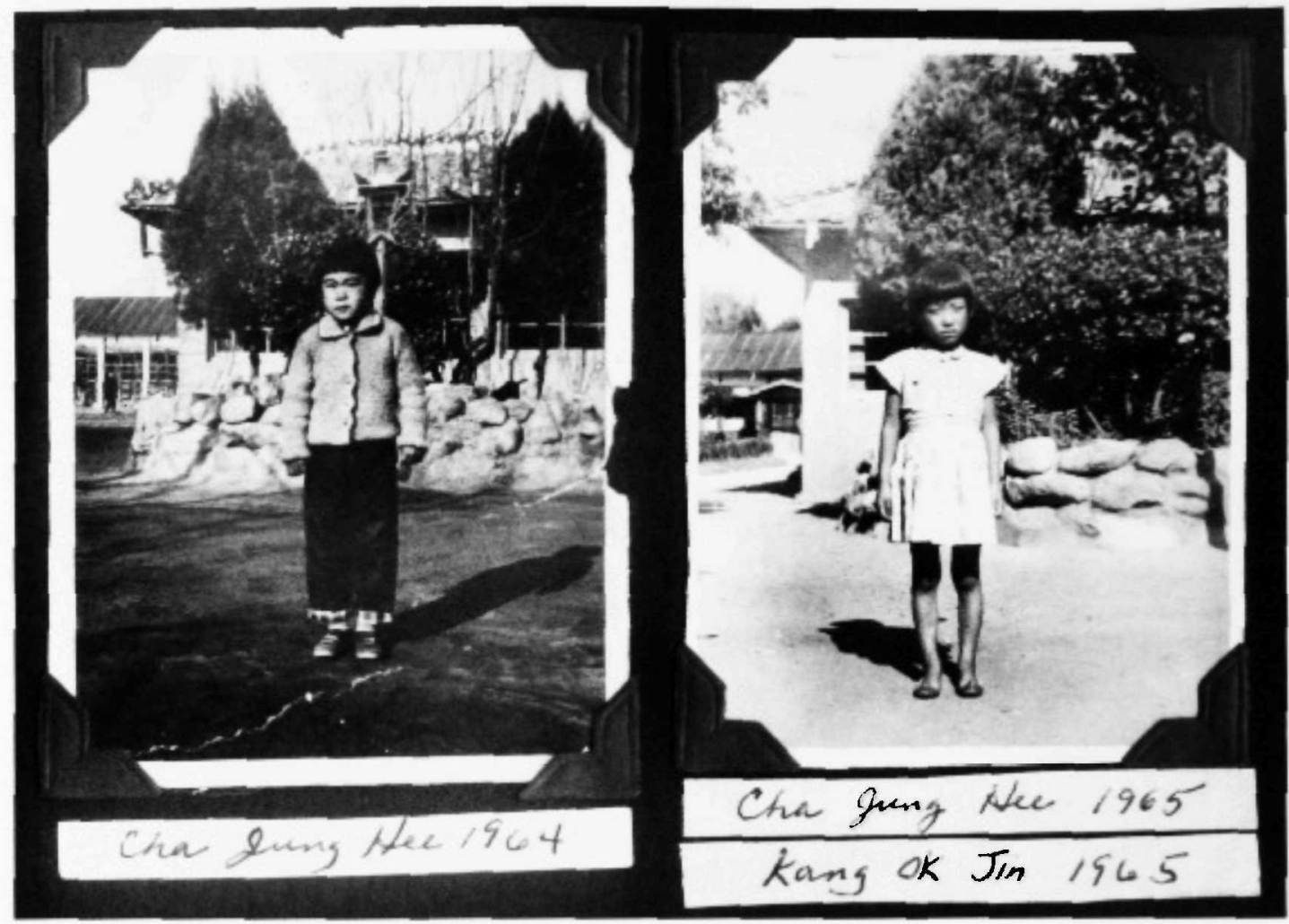

The two Cha Jung Hees. Courtesy: Borshay family.

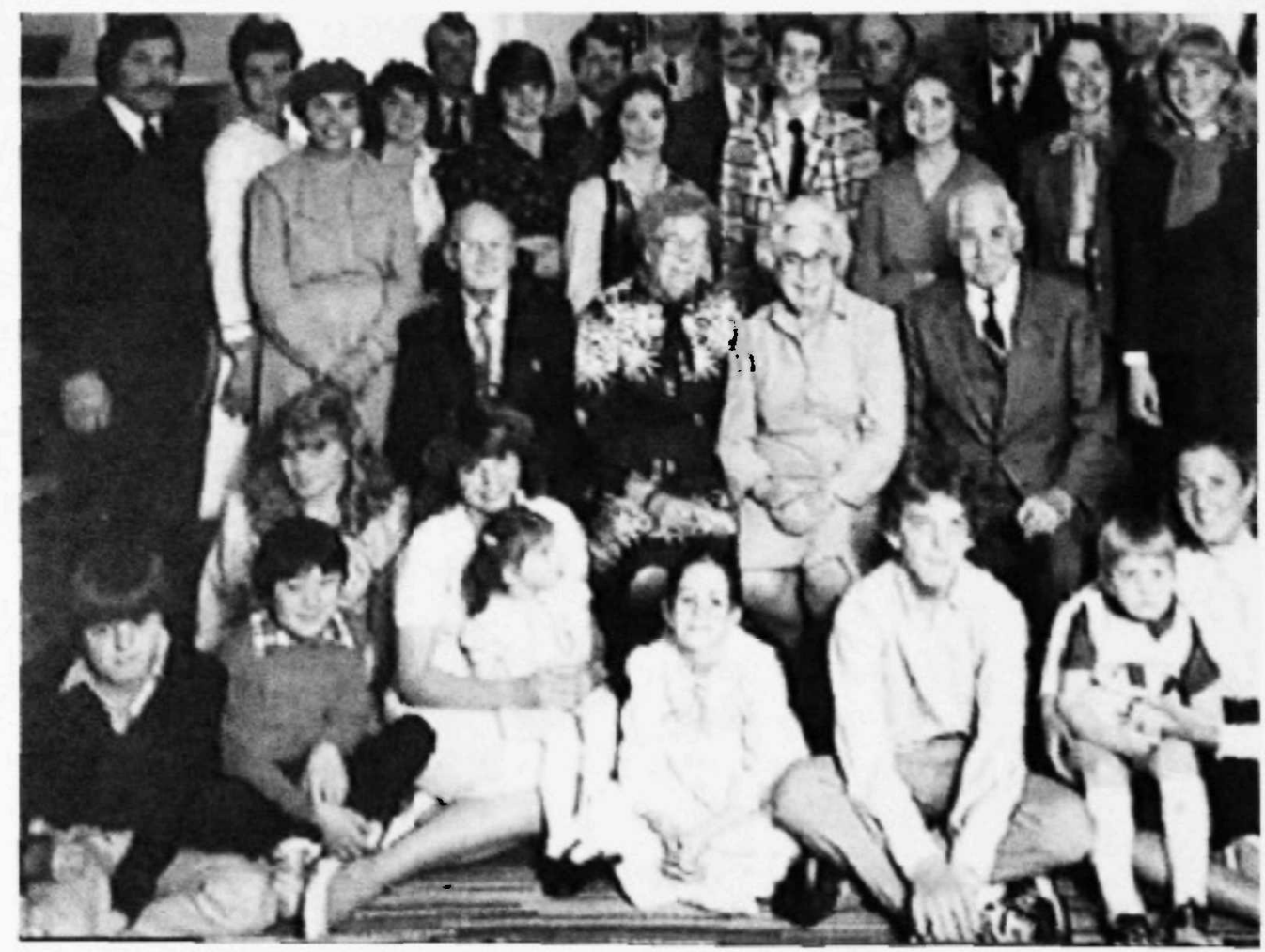

"I understand that you're Asian, but you're also Nathan Adolfson, part of the Adolfson family."From Passing Through. Courtesy: Nathan Adolfson. 
calling you Long Duck Dong and I thought that was terrible. ${ }^{35}$ I didn't probably defend you like I should have."

Deann Borshay's father was an amateur filmmaker of home movies, and she uses many of the images from his $8 \mathrm{~mm}$ films in her own work. She also reflexively acknowledges the shift in power dynamics, displacing his authority as the sole producer of familial truth. In many shots, she is taping him taping her. and this is most clearly foregrounded in the beginning of the video, in which Deann's face is distorted through visual effects in her father's video camera. The voiceover we hear is her introducing her multiple identities. She then gets up and walks over to another camera set up on a film and the construction of the caltegory and practice of "home movies" (in contradistinction to Hollywood movies). Inscribing a private, self-enclosed ideal of family life, "home movies," Zimmerman writes, "conscripted 'togetherness.' family harmony, children, and travel into a performance of familialism" (133). In Borshay s case, it conscripted her into an all-American life (family vacations, school performances. high school cheerleader, and homecoming queen) until memories of Korea started coming back to her in her twenties. Home movies also inscribed a patriarchal division of labor, in which the favored and prescribed subjects of home movies were children-they served to objectify the family from the point of view of the patriarch. As

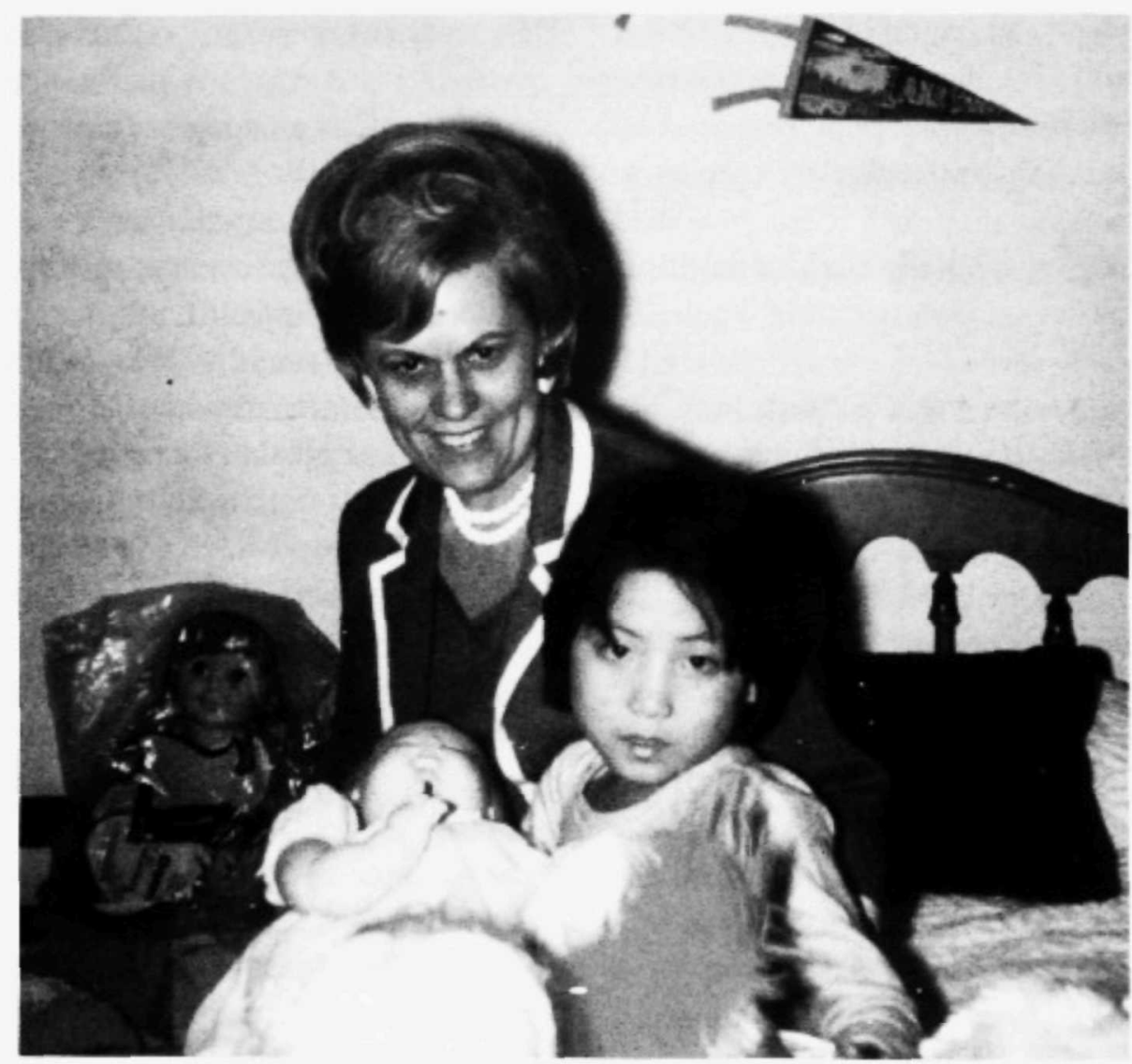

Young Deann Borshay Liem with her adoptive mother. Courtesy: Borshay family.

tripod, which is taping (as surveillance?) her father as he watches Deann through his flip-LCD screen.

As Patricia Zimmerman (1995) writes in her history of amateur film, the expansion of leisure time. along with the commercialization and professionalization of leisure-time activities among the American middleclass in the 1950s and 60s, resulted in the rise of amateur
Borshay says, "The only memories I have of $m$ ! childhood are the images my father filmed as I was growing up. I relegated my real memories into the categories of dreams." It wasn't until she was almost 40 years old that she went to Korea with her adoptive parents, to make her own document of memory, in dialogue with both sets of families. 


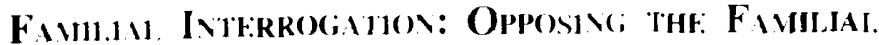

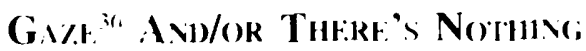
IVovi with This PICTle.

"I telt like I was supposed to choose one family over another. Over time. I realized I needed to see both families together at the same time, in the same room. I thought that if I could actually see them come together in real life, that somehow both families could then live within myself." First Person Plural (20)(0) $)^{37}$ is a gripping and courageous work which documents Borshay s attempt to grapple with the reality of having two families, especially two mothers: "I didn't know how to talk about my mother with my mother." Speaking into the camera. to an invisible interlocutor/ intervicwer. she gives a psychotherapeutic display of her feelings, fears, and memories, working out in real time her conflicted feelings about her adoptive parents, and the clash of fantasy and reality provoked by coming to Korea.

Borshay', film begins with the ideal of multiple identities and histories:

My name is Kang Ok Jin. I was born on Junc $14^{\text {th }}$ 1957. I feel like I ve been several different people in my life....My name is Cha Jung Hee. I was born on November $5^{\text {th }}$ 1956. I've had three names. three different sets of history....My name is Deann Borshay. I was born on March 3rd 1966. the moment I stepped off the plane in San Francico. I've spoken different languages. and have had different pasts.

Interweaving personal voiceover and direct address with interviews with her adoptive parents and siblings. Borshay describes her childhood in a quintersentially 1960) American setting in northern California. Visually, she uses archival footage from Korea in the 1950s, family snapshots from her biological family in Korea and in Americal and home movies taken by herfather. As a member of the Borshay family, Deann appears as a happy, smiling. well-adapted young girl who was "the baby." and clearly her parents" favorite child.

After describing how she found out that her adoption papers had been falsified. and that she is not the child her family thought she was. the remainder of the film documents Borshay's return to Korea with her adoptive parents. to meet her biological family. For Borshay, this meeting was necessary to make real for her the two realities which composed her life. Unable to communicate freely due to the language barrier with her biological kin. she finds it difficult to convey her feelings and to fully comprehend the words and tears of her biological mother. By accepting the distance beiween herself and her biological family, however. she is able to let go of the childhood fantasy of being reunited harmoniously with her "real" family. Ultimately, she realizes that what constitutes "family" is the relationships of love built over time, and that she needs to work on building such a relationship with her biological mother: "The only way for me to be closer to her is to acknowledge that she has not been my mother for over thirty years, and my other mother has been mother - in a way. my real mother."

In the Korean adoptee autoethnography of Adolfsion and Borshay, the family frame is undermined through the direct confrontation of the adoptee with his/her parents. Using the camera. the familial gaze is reversed and exposed. and difficult. suppressed questions are recorded and made visible. "There was an unspoken contract between us which we had all agreed upon. but never discussed. that I was an orphan with no family ties to Korea... I belonged only to my American parents. It meant I didn't have a Korean history or a Korean identity" (First Person Plural). Yet both Adolfson and Borshay, after deconstructing the family frame, ultimately come to reintegrate themselves into it. into the context in which they have been socialized. With an apprehension of the significant emotional work that having a biological family will entail. they embrace their adoptive families as "real" after all.

In Borshay"s film, selections from conversations with her American parents are used in way's that oppose the images of Deann presented in the photographs and home movies. These conversations also revial the ways in which her own emotions or difficulties in adjustment were repressed under the desire to produce the unproblematic family unit represented by the Borshay family archive. Her mother talks about the day she arrived at the airport: "When you arrived, little storic face. bundled up in all those clothes. and... we couldn't talk to you and you couldn t talk to us. I realize now that you were terrified. but because we were so happy we just didn't think about that." And her father remembers the first family meal: "Mother had prepared something 
that was very nice. You dropped your head and tears started to come down. No words were spoken! Mother perceived what was happening and took you away from the table. and you were excused. and from then on everything was perfect." For Deann, however, "every. thing was perfect" only if she could "fit in." Images of Deann as a high school cheerleader, jumping and smiling and looking very all-A merican. are matched with her rumination: "I think somehow I have created a collage of things and made myself over to fit all the little things I had seen in my life."

Nathan Adolfson. a graduate of UC.LA film school. is an adoptee from Anoka, a small tow n in Minnesota. " In his "personal diary documentary" Passing Through. he documents his time in Korea. finding community and searching for his birth parents. much like Jennifer Ardnt in Crossing Chasms. Unlike Arndt. however. who seek answers from other adoptees. Adolfson uses interviews with his adoptive family to punctuate his documentary footage of Korea with his "normal "life in Minnesota. From the beginning. it sclear that Adolfison is at a turning point in his life: considered "odd" by his family-_." the one who lives in California" - an outsider who made the strange decision to go to film school. His mom exclains. "I mean. it"s odd. it"s very odd. I mean. good grief. how many people do we know that go to film school?"39

He takes out a student loan to spend six months in Korea. enrolls in the Yonsei Language program. ${ }^{+10}$ and finds it to be not unlike high school. "except now. I have a camera to record my alienation." His voiceover guides the viewer through his impressions of and feelings about Korea, initially ones of overwhelming disorientation and unreality. As he documents a student protest demonstration at the gates of Yonsei University. the tear gas begins to choke him. and he turns the camera on himself. his mouth covered with a bandana and his eyes streaming: "As I'm watching it, it doesn't scem real. that is. until the smoke and tear gas start cutting off the air to my lungs... Then it becomes real. It becomes real and it becomes clear that I don't know what I'm doing here. Not only at this demonstration, but here in Korea." $" 1$

The progression of the film shows Nathan arriving in Korea without much emotional connection. and no memories, but with a deep fascination. He leaves having found his biological family and having learned how to accept the contradictions and complexities that come with heing an adoptee with tuo families." Interviews with his family in Minnesota are intercut with his Korcan footage. and family snap shots are used to illustrate, sometimes ironically, his life in Minnesota. In one instance, his brother a construction worker. who denies having bullied Nathan when they were growing up. says. "well you just touch your nose and it bleeds." and we see a photo of him posing proudly with a huge. bloody, freshly killed deer carcalss.

Pictures of Nathan in elementary school classes and family photos, showing him smiling and looking like a "normal kid," are matched with his mother"s voice describing the lack of allareness that he and her husband had of the problems he may have faced an an Asian child in small town Minnesota: "We really didn't think it was that you were having problems. You never said anything. Never said a rord.... We probably did try to raise you as being too American. or too... maybe we weren t sensitive enough to your heritage... tried to turn you into a little Scandinavian."

Much like Zinmerman's discussion of fimmlialist ideology and the practice of home movic making. Marianne Hirsch in Family Frames (1997) describes the function of the family photo in inscribing the dominant ideology of the family and family life:

The family photo both displins the cohesion of the family and is an instrument of its togetherness: it both chronicles family rituals and constitutes a prime objective of those rituals... As photography immobilizes the flow of family life into a series of snapshots, it perpetuates familial myths while seeming merely to record actual moments in family history. At the end of twenticth century, the family photograph. widely available as a medium of familial self-presentation in many cultures and subcultures. can reduce the strains of family life by sustaining an imaginary cohesion. even as it exacerbates them by creating images that real families cannot uphold (1.3).

The family photographs that appear in the films and videos of adoptees stand in evidence and memor! often of an unsustainable. "imatginary cohesion." The adoptec. an Asian fice encompassed in the family frame. disturbs the picture of the dominant white American family. Like the semiotic destabilization which comes from discovering that a "white" person"s name is 


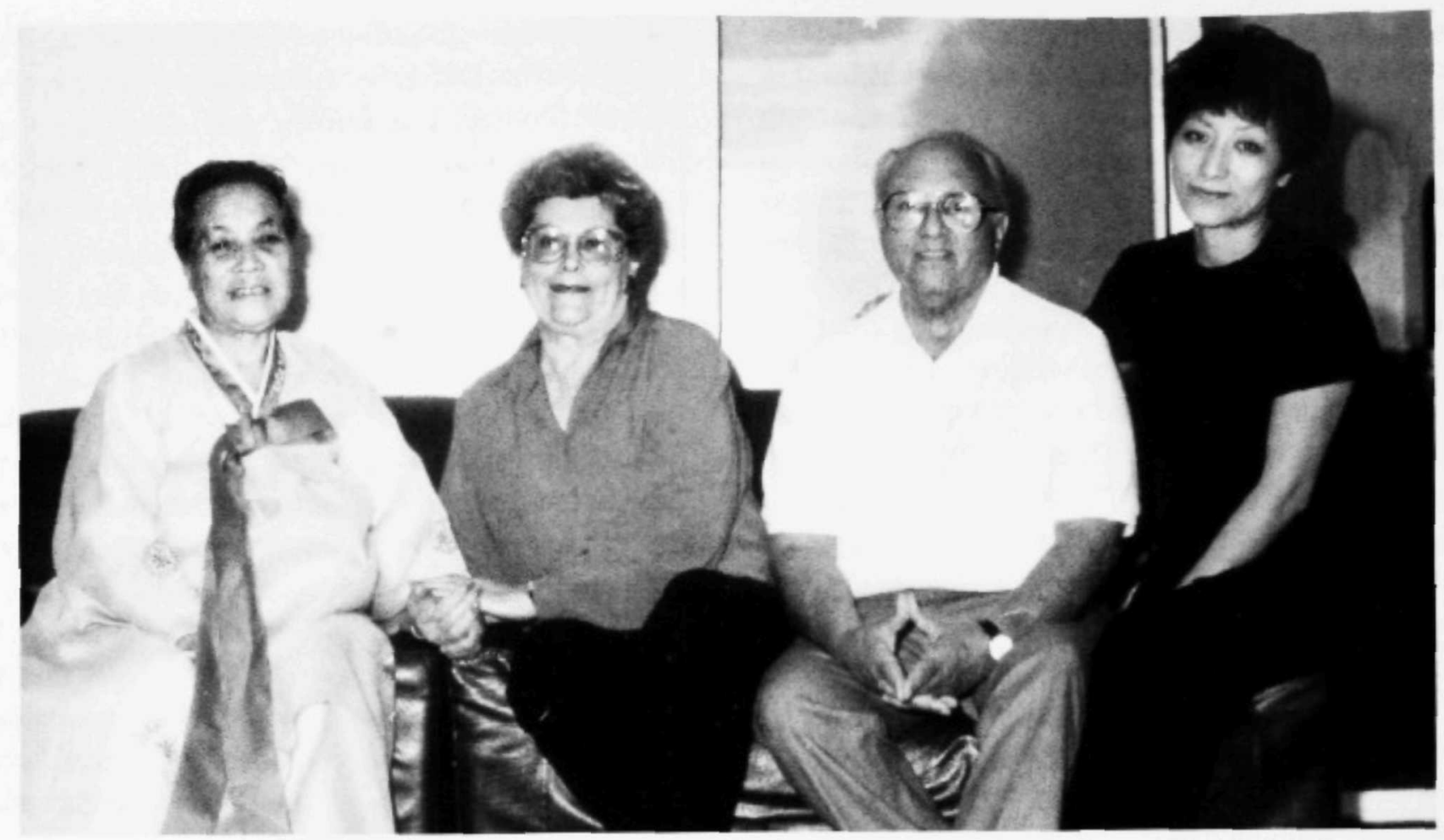

Filmmaker Deann Borshay Liem and parents. Courtesy: Kesong Kim

attached to a person with Asian physiognomy, family photos present a challenge to normative assumptions of what families should look like. rupturing the visible coherence of social and racial homogeneity of which the photograph becomes an index and an icon. As Marianne Hirsch notes. "photography's social functions are intimately tied to the ideology of the modern family" (13).

The photos, therefore, indexically represent the assimilation of the adoptees into an idea of the "allAmerican family." fully interpellated into the family frame as a smiling, hatppy, normative member. The interviews with kin relations underscore this naturalization of a racially-other individual into the white household, with siblings insisting on their adopted brother or sister as just "one of the family." Yet for the adoptees, undergoing a search for self and scrutinizing their pasts through the process of producing these films and videos, the family snapshots stand as a kind of false consciousness. They speak to the adoptee's complicity in the suppression of his or her oun difference under the powerful pressure of the familial gaze.

"The powerful gare of familiality ... imposes and perpetuates certain conventional images of the familial and ... "frames' the family in both senses of the term" (Hirsch 1997: 15). Hirsch's theory of the familial gaze. in considering the photos of transracial and transnational adoptive families, presents a useful way to think about the ways in which adoptees and families construct themselves as "family." in relation to the dominant American myth. For the adoptees in these films, and as expressed in other sites of adoptee activity. "family," for both adoptee and adoptive parents. is represented as an achievement. something that cannot be taken for granted, given the very different path that the adoptee's life may have taken in Korea. Many of these adoptees grew up in predominantly white communities where they of ten were the only people of color in their schools, churches, neighborhoods and other social institutions, and despite the increasing acceptance of heterogeneity. interracial matriage and dating, there are, as always, significant hurdles of racial discrimination which continue to interpret bi- or multi-racial families as deviant. "unnatural," or exotic.

The pressure of the familialist ideology and its potency is made further legible through the defamiliarizing of those relationships following the adoptee's reunion with biological kin. ${ }^{44}$ Borshay addresses this defamiliarization which emerged for her as an adult: Sometimes I look at them and I see two white American people that are so different from me that I can't fathom how we are related..... When they adopted 
me they really accepted me as their child. And I really became a part of their family - and even though I wasn't related to them by blood. it was as if I had been born to them somehow." Like Borshay. Adolfson's film documents a rite of passage, achieving a more mature conception of himself and his relationships. Commenting on his dual family, he says, "I have been given a new family, and I know now I need to learn about my new Korean family, as well as my true family back in Minnesota."

The "as-if genealogical" relationship that Judith Modell (1994) describes in her ethnography of American activist birthmothers is an adaptation of the dominant model of kinship in America which measures authenticity of $k$ in by blood, not affiliation (cf. Schneider 1968). The power of this ideology is apparent in Adolfson and Borshay's videos. Both of their adoptive families, despite their differences in age and generation, share in the familialist ideology, expressing no doubt that despite the lack of a biological tie, and despite the racial and ethnic differences, that the adoptee was "family." And the adoptees themselves embrace this notion after coming to terms with the felt ambiguities and contradictions regarding the social relations and emotional investments that constitute the "true" family. ${ }^{45} \mathrm{At}$ the end of their journey, these adoptees return to defend the legitimacy of adoptive kin relations by rewriting the truism of procreative kinship: "Blood may be thicker than water. but love is thicker than blood. "to
Mainstream representations of domestic adoption in the U.S. media have been historically negative, sensationalistic, and marked by a fascination with search and reunion (see Reese 1997 and Waggenspack 1998). Representations of transracial, transnational adoptees have been scant, but growing acceptance is notable in advertisements and television news shows which represent these adoptions as touching, humanitarian gestures by Americans (usually celebrities) who, like all of "us." believe in building loving families. These positive depictions of adoption are indications of a shift in popular consciousness. projecting inages of adoption as a legitimate form of family life in America ${ }^{47}$ Rosie O Donnell, an adoptive mother of two boys and an enthusiastic adoption advocate, recently devoted an episode of her talk show to domestic adoption which featured a gay couple from Miami who had adopted two HIV-positive children from foster care. Last year's Super Bowl Sunday pre-game show protiled former quarterback Dan Marino and his adopted Chinese baby girl. A Merrill Lynch print advertisement in The New Yorker shows an image of a white classical musician couple in rehearsal. next to an image of an Asian toddler's face. The mother says, "The arts is not the most stable career. Then. when you have a child. the uncertainty really hits home." ${ }^{\text {+8 }}$ Transracial adoption here is coded as unremarkable: adopting a child of

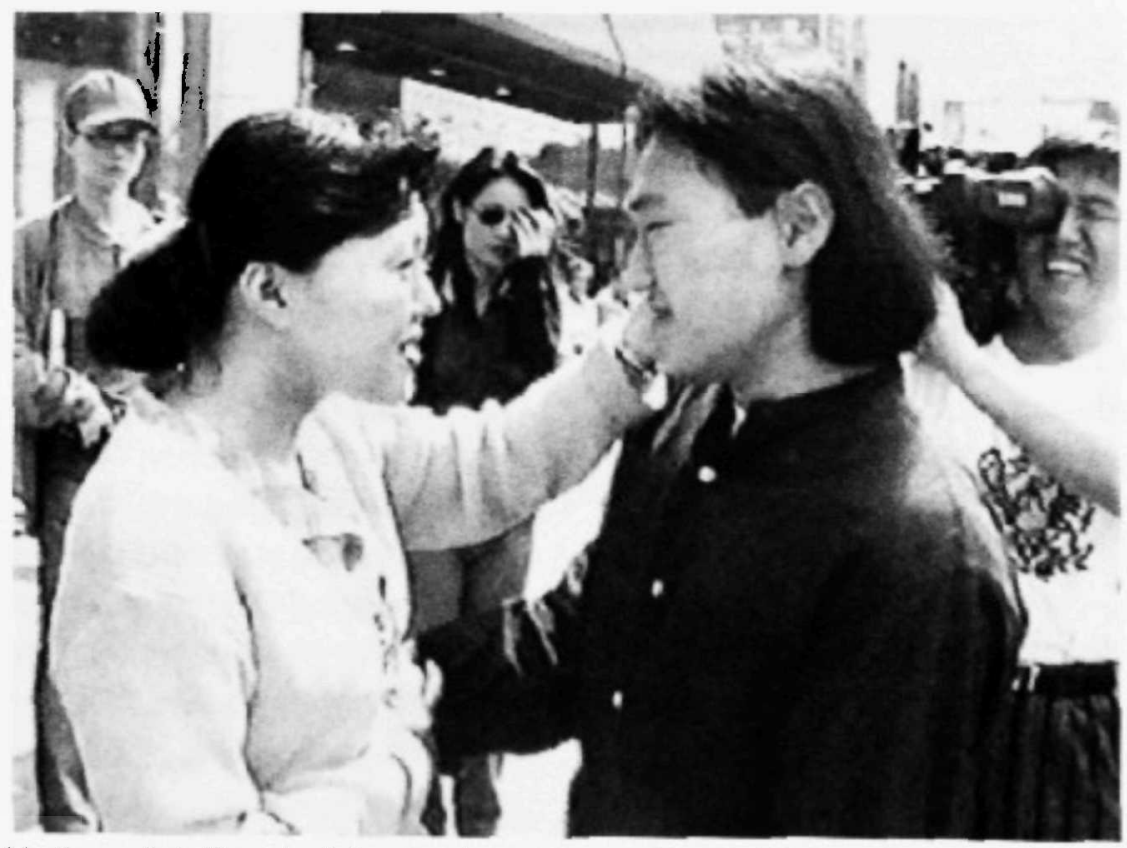

Nathan Adolfson's televised reunion with his sister. From Passing Through. Courtesy: Nathan Adolfson. 
another race is thus naturalized into the larger middleclass American ideal of building a secure financial future for one's family, and especially for one's children. The advertisement subtly encodes the naturalness of adoption through a semantic slippage between adopting and giving birth: "when you have a child."

These examples are perhaps indications of the waning of the dominant model of the mono-racial American nuclear family. Notions of acceptable family structures in the Hest have altered significantly in the past two decades. with recombinant families, femaleheaded households, gay and lesbian unions. among others, presenting themselves as alternatives to the dominant biogenctic definition of the "family" (Peletz 1995: Weston 1991). When it comes to children. however. conventional wisdom and legal precedent stress the sanctity and inalienability of biological parenting. and conservative political rhetoric continues to posit a calusal link between non-normative family arrangements and transgressions of "family values" as generative of social ills such as poverty. drug use or crime.

The increasing faith in biogenetics and scientific representations of social and cultural phenomena contributes to a widely-held notion of biology as destiny. Many adoptees who search for their biological kin emphasize the importance of medical information. especially if they have started. or are planning to start. families of their own. Yet as Katrinal Wegar (1998) notes, the psychological and affective dimensions of social connectedness are also very strong: "Adoptees" search for blood relatives confirms that blood relations still matter despite the upsurge in divorce rates and single parenthood. The molecular connection still implies a sense of belonging. continuity and care that makes families-and society-possible" (1998: 41). And. according to the Evan B. Donaldson Adoption Institute, a major adoption research organization. half of the American public believes that adoption "is better than being childless, but not as good as having one"s oun child" (1999a: 1). Indeed, constructions of adoption as "deviant" have been reproduced by media representations which portray adoptees as socially maladjusted. troubled or even violent. How these representations might alter with the increasing practice of open adoptions and the growing strength of the domestic adoptee movement (which has won important legal battles in the recent past), is yet to be seen. ${ }^{+1}$
In the case of transracial. transnational adoption. the importance placed on medical information. while undoubtedly of significant concern. may also be a way of distancing the more difficult emotional issues around the search by displacing it onto the molecular. For the many adoptees who are locating their biological parents. seeing people who look like them for the first time. finding similarities in physical features and making connections to genetically-coded characteristics, is an extraordinary and unprecedented experience, a fantasy come true. " As Kimberly SaRee Tomes says in Looking For Wend,:

A sense of natural family and history is available in daydream and fantasy." At the same time. however. the desire to see biology and heredity in the flesh places the adoptee in a difficult position with respect to their adoptive families. often producing a fear of divided loyalties, or of a betrayal of his or her adoptive family. Biological family connections become a source of anxiety because of their ability to disrupt the "as-if genealogical" relationship. as was the case for Borshay"s mother. for whom the prospect of her unearthing a Korean family was a frightening and unheard of proposition. As she says. "To us, an orphanage meant you had no family.

Korean adoptee autoethnography must also be considered in the context of mainstream and local depictions of Korean adoptees. Korean adoption has had its fair share of negative media attention. with the Bryant Gumbel exposé of 1988. and the scandalous affair of film director Woody Allen and Soon-Yi Previn-an adopted Korean raised by Allen's former wife Mia Farrow-as two major examples. A dominant Korean mis-representation is epitomized by the television soap opera Susan Brink's Arirang (Jang 1991) which projects and perpetuates negative stereotypes of overseas Korean adoptees. It portrays a Korean adoptee in Sweden who, as a teenager. escapes from the slavery and abuse of her adoptive family and is redeemed through her reintegration into an authentic cultural "lamily" among a local Korean diasporic community. One adoptee. in describing the spuriousness of Susan Brink's smooth assimilation into the Korean community. commented sardonically: "Of course, she remembers how to speak korean instantly." 
Adoptees have expressed feelings of distance and disapproval from the Korean American community as well. Nathan Adolfson begins dating a fellow Korean American student while at the Yonsei language program, but their relationship is short-lived, for as he informs us, her "traditional Korean family" insists that she break up with him: "The reasons being that I'm an aspiring filmmaker. and that I' $m$ adopted, which means
Koh recently released True $(2000)$ ) a coming-to-ethnicidentity film whose protagonist is a Korean adoptee, and Ty Parks' Cor Kurea Chy (1999) features a Korean adoptee as a narrative vehicle to represent the tragedy of separation resulting from the division of Korea.

As well as resisting and opposing these representations and cooptations, Korean adoptee autoethnography performs a necessary. and indeed, existentially

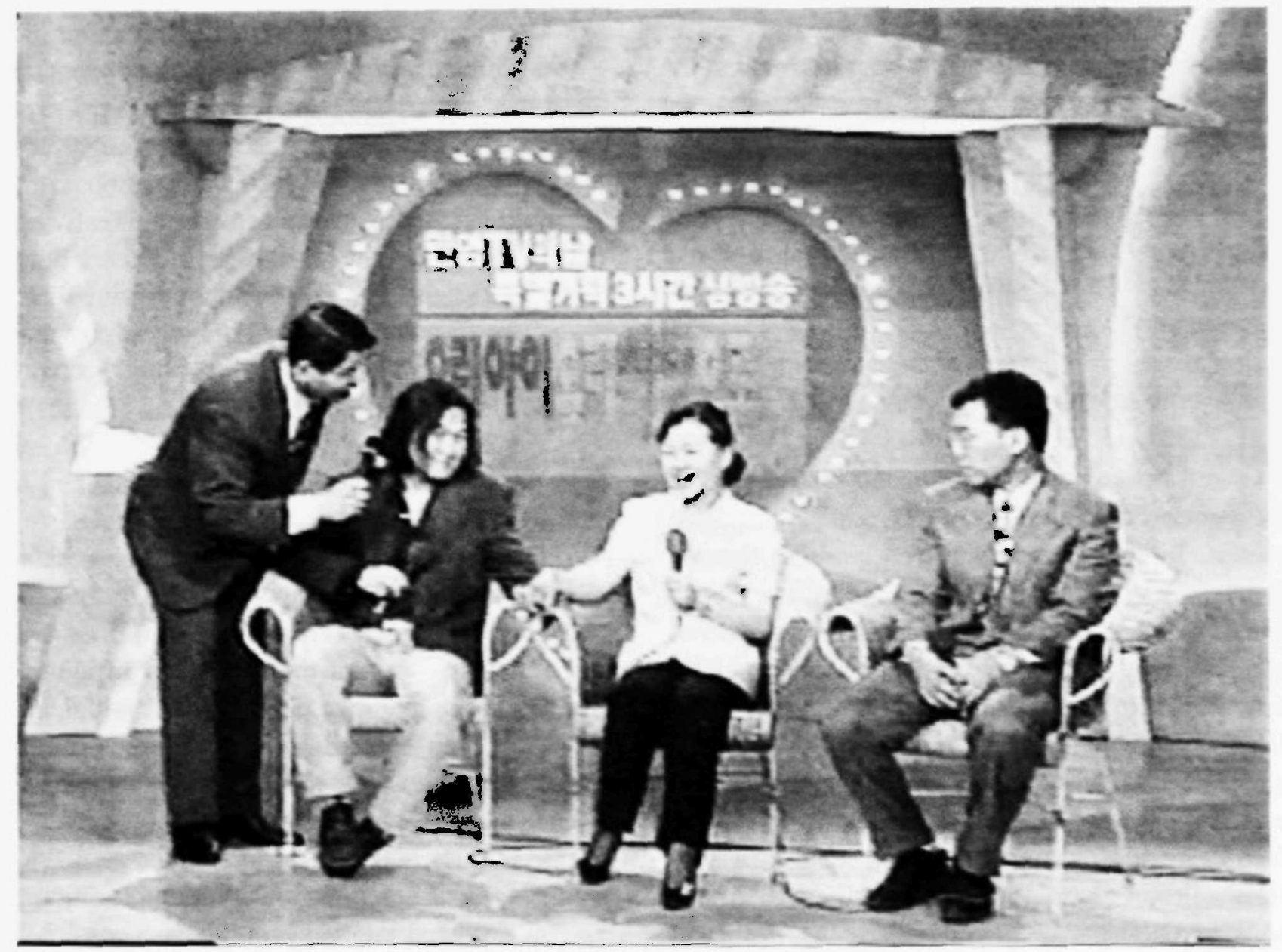

Nathan and his biological sister and brother on Korean national television. From Passing Through. Courtesy: Nathan Adolfson.

that I don thave a good bloodline." At the same time. however-perhaps in response to the increasing vocality of Korean adoptees-Korean American community organizations are recognizing Korean adoptees through targeted outreach and inclusive cultural programming. Korean adoptee experience has. in fact, already been coopted by Korean American artists who are inspired by the displacement and destabilizations of identity symbolized by the adoption experience. Filmmaker Jay urgent cultural work. The texts exist as forms of cultural memory. and in their polywocality, perform a dialogic reconstruction of the past. These are attempts to fill in formissing histories to(re)signify semiotically-crippled photographs and documents that exist in potchitia. but which are severed from the indexical, embodied reality from which they originally emerged: They cannot speak. In their work of piecing wogether recovered memory and forging meaning through self-examina 
tion and narrative, these films and videos are. ultimately, records of the struggle for personhood.

This struggle is one that could be seen as a paradigmatically American one, organized around the individual ego and the resolution of a problematic identity. The Korean adoptee autoethnography. as a "journey of the self," is motivated by the desire for selfknowledge. to answer questions about severed biological relations and irretrievable memories. At the end of this journey, however. the filmmakers arrive at different destinations or junctures. to different degrees of resolution or coherence. Each comes to understand the self ats socially constituted through kin relations, both biological and adoptive. and as multiply inflected by biology, culture. history and the social. The experimental films of Alin. Theiler, and Tomes use non-linearity and formal devices to evole a fractured and multiple subjectivity. leaving open the indeterminate connection, between the valences of history, hiology, kinship. and identity. The search and reunion documentarists. on the other hand. are more wedded to the self as a coherent entity, and organize their journeys in a linear narrative that brings the question of the self to resolution. however uneasy that may be. What links these approaches. however, is the shared recognition and acceptance of "living in halftones." of being a hybrid subject. of existing between social categories, and of belonging to two families, across cultural and national borders.

They document the search for self and identity through different aspects of adoptee experience such that personal autobiography becomes what Teshome Gabriel refers to as "a multi-generational and transindividual autobiography. i.e.. a symbolic autobiography where the collective subject is the focus. A critical xcrutiny of this extended sense of autobiography (perhaps hetero-biography) is more than an expression of shared experience, it is a mark of solidarity with people"s lives and struggles" (cited in Xing 1998: 93). Gabriel was writing in the context of Third Cinema, and although Korean adoptees as a group are not an organized political collective. there is. I believe a growing sense of a "collective subject." if not a collective project.

The Korean state has made major acknowledgments of adoptees as part of the overseas Korean "family." and Korean society in gencral has. according to some adoptees. become more open to acknowledging them positively, rather than as objects of pity or shameful reminders of social deviancy or the nation's onetime Third World status. As Ardnt shows in her video, returning adoptees like Mi-Hee Lemoine, a Belgian adoptee who was reunited with her Korean family in 1991. have started providing support for other adoptees who are beginning the arduous process of searching. and due to their efforts, possibilities for finding information about biological families have increased substantially.

The liberalization of official Korean attitudes towards adoptees is undoubtedly an outcome of "globalization." an increasing interest in the West, especially Americal. and a desire to embrace overseas Koreans as a "bridge" to the global West. Transnational flows and circulations have created more opportunities for adoptees and biological families to find and meet each other, with electronic registries and the Internet providing faster and more efficient means of tracking information. The experience of modernity has also altered perceptions of social relations-what Giddens (1990) calls "disembedding." the "'lifting out" of social relations from local contexts of interaction and their restructuring across indefinite spans of time-space" (cited in Tomlinson 1996: 67). This phenomenological shift has allowed all sides of the adoption triad an unprecedented opportunity to think across space and time towards a more inclusive idea of family. ${ }^{5 t}$ This difficult process of reconciling adoptive parents with biological kin. as represented in these auto-ethnographies, is one that many more adoptees are now facing, and adoption agencies are responding by incorporating search and reunion issues into their pre-and post-adoption counseling services helping adoptive parents anticipate and prepare for what is now becoming an expected stage in the adopted person's lifecycle. ${ }^{52}$

All of the artists discussed in this paper are continuing to be active as media artists, pursuing their personal and political investigations of the adoptee experience: Borshay's current project is a historical documentary about Korean international adoption. and Ahn. Arndt. and Adolfson are all working on narrative films based on their experiences as adoptees. And no doubt. many more adoptees are producing their first films and videos at this very moment. The role of this work in producing "communitas." or a "counterpublic" (Fraser 1992) is yet to be seen. and with the diversification of media content and the emergence of new forms and sites of 
exhibition. the future production and circulation of these representations will deserve further study. As Schein $(2000)$ writes about Hmong videographers. distributors. and viewers, "through various modalities. emergent translocal interchanges redraw the horizons of ethnic community. stretching the bounds of the national" (3). For adoptees, the primary displacement from the "home" country is provisionally recompensed through the self-transformation effected through the work. Korean adoptee auto-ethnography, as film and video representations of the search for identity. is a mode of refashioning the self and of performing subjectivity, of "repair|ing] the broken narrative." and perhaps. of laying the ground work for an "imagined community."

Achomitho;itwe

I would like to acknowledge Christine Gailey for her assistance in my initial research. and So Yun Roe for close readings and helpful comments on an early draft of this article. Thanks also goes to the anonymous reviewers for their insightful critiques, and appreciation to the filmmakers for sharing their work with me. I am especially grateful to Faye Ginsburg for her encouragement and critical feedback in guiding this work to completion.

Nomis

I. Fischer" $>$ attempt to describe a paradigm for "ethnic autobiography" draw's attention to the counter-discursive productions by people of color as interventions into dominant Anglo-American narratives, yet it is limited in its attempt to construct a totalizing framework for "ethnicity" and ethnic experience. Indeed. what he says of "ethnicity" need not be restricted to that valence of identity. and might be applied to gender, sexual orientation, and other aspects of personhood (Russell 1999: 312). Nevertheless. his promotion of the emergent qualities of identity and memory in the active construc. tion of subjectivity - through aesthetic forms such as literature or film-still provide. in my opinion. a relevant and productive framework.

2. This section can only offer a brief overview of the history of Korean adoption to the U.S. and Europe. The broader social history and political economic context exceed the scope of this paper.

3. Unlike China, however. the overall gender ratio of children from Korea since 19.55 hats been roughly 58 percent girls to 42 percent boys. Anecdotal evidence suggests that preferences of Korean domestic adopters have shifted from boys to girls. leading to a surplus of male children alvailable for international adoption. One major American adoption agency reports that 9.5 percent of their placements of Korean children are male. A possible genealogical rationale may be behind the domestic Korean adoption trend: adopted girls present a less problematic future for parents concerned with maintaining the purity of the bloodline. An adopted boy would represent a break in the bloodline, whereas a girl. adopted or otherwise. Would eventually marry out of the family.

4. According to Jong-sool Lee. director of Holt Children "s Services in Korea, of children being adopted today, 97 to 98 percent of them were borne to single mothers in their teens and early twenties. (Park 2()(o()).

5. South Korean Ministry of Health and Welfare.

6. The Five Year Plan for Adoption and Foster Care (1976-1981) was intended to encourage domestic adoption (Sarri et al. 1998).

7. Bryant Gumbel. on NBC's Today Show, gave a report on the "export" of Korean children in 1988. This was one of the first mainstream exposés of transnational Kurean adoption. and set off a slew of negative press reports.

8. The United States is the primary receiving country for transnational adoptions in the world. Advertised by some an the "Cadillac" of transnational adoption programs. Korean adoption services provide a streamlined process for delivering healthy infants who are wellprovided for by foster families. This is in contrast to the fear and uncertainty that characterize Russian and Eastern European adoptions. where behavioral and neurological problems related to institutionalization have been widely reported.

9. OAKis is an acronym coined by Global Overseas Adoptees Link (GOA L), a Korean adoptee adrocialy group started by adoptees in korea.

10. One of the earliest adoptee organizations. Minnesota Adopted Koreans (MAK), unbeknownst to Ahn. was started in 1991 by a small group of adoptees in Minnesota.

11. Although the overwhelming majority of adoptions were by white Americans, it should be noted that there have been exceptions in which adoptees were raised by Korean Americans or other Asian Americans. Me- $k$. 
Ahn's mother, for instance, was Japanese American. and some adoptees were raised by Korean Americans. Currently the Korean government is advocating adoption of Korean children by Korean Americans and adult Korean adoptees: and agencies are giving overscas Koreans preference over non-Koreans. Other major receiving countries of Korean children have been France. Sweden and the Netherlands (Korean Ministry of Health and Welfare: Kane 1993).

12. The model of sealed records domestic adoption policy probably provided the precedent for this attitude. For children adopted in the U.S.. new birth certificates were issued which. in effect. legalized the biological connection between children and their adoptive parents. erasing any trace of the original parents (cf. Carp 1998: Modell 1994: Wegar 1997). Recent legal battles have been won by adoption advocates in Oregon and Tennessce, allowing adult adoptees the right to view their original birth certificates. which include the names of their biological parents. As in Korea. where the social censure of oul-ot-wedlock births and adoption is high. much fear has been expressed by biological mothers in this country. In Oregon. a counter-movement by a group of biological mothers formed in opposition to the open records bill. declaring that they had been guaranteed privacy and confidentiality at the time of the adoption. and that the disclosure of this information had the potential to have detrimental psychological and social effects on themselves and their relatives.

13. Many adoptees incorporate their Korean names into their American names, inserting it between their first and last names, literally splitting it in two. Deann Borshay Liem has a particularly interesting case regarding her "authentic" name and the slipperiness of identity, though she retains the name her parents gave her. and takes on her husband's A sian surname. Me-K. Ahn. adopted by a white American father and Japanese mother. is a "created name," the origins of which she summarizes in Jennifer Christine Yang Hee Arndt"s Crossing Chasms (1997): from her American name Karen Muckenhirn. to Karen Me-kyung Muckenhirn. to Me-K Ando, to Me-K. Ahn. Me-kyung was the name given to her by the orphanage. and she later shortened it to Me-K. Ando is her adoptive mother's maiden name. and $A h n$ is a Korean transliteration of Ando.

14. Once ignored and conveniently forgotten by the Korean state, adoptece are now gaining positive recognition from the Korcan government under President
Kim Dae Jung (and through the interest and encouragement of First Lady Lee Hee-ho). Adoptees are now included in visa laws for overscas nationals. allowing them to stay for up to two years. to find employment and to buy land.

15. According to Korean Quarterly (1999), adopted Koreans first arrived in Minnesota in 1959. By 1990. a rough estimate of the state's Korean adoptee population stood at 15.00(). compared to 8.000 to 10.000 for first- and second-generation Korean Americans. In 1998. the figures for adopted Koreans were around 17.000 to 20.000. and around 10.000 to 12.000 for immigrant and second-generation Korean Americans. By these figures, adopted Koreans in Minnesota account for around 2() percent of the total U.S. Korean adoptee population.

16. Certainly, not all adoptees have had ideal family environments. Many have had very painful and troubled expericnces, with cases of child sexual abuse, mental illness and drug abuse in adoptive parents and psychological stress and socialization problems for the adopted individuals not uncommon (see Tolle 1998).

17. SoYun Roe, the wife of an adoptee. was project director of the SNAPSHOT exhibit at the Korean American Museum in Los Angeles (July 1999), the first exhibit to focus on Korean adoptee history and experiences. She described the motivation for developing the exhibit: "The timing was perfect. Korean adoption was on the verge of a kind of coming of age. Korean adoptees. who in most cases grew up believing that they were the only individuals of their ilk, were beginning to find each other and reach their critical mass and awareness... with half of all Korean adoptees now adults, it was clearly time for this first half to share its experiences with the second half and with each other." 18. The ways in which this group identity is being constructed in the context of dominant discourses in 20th century American culture (multiculturalism. family values. Cold $W$ ar) and in relation to U.S.-Korea relations and history are too broad to be fully addressed in an essay of this length and scope.

19. Rea Tajiri's History and Memory (for Akiko and Takeshige) (1991) has been exemplary and inspirational for many Asian American filmmakers in this regard.

20. The age at which adoptees were sent abroad certainly has much to do with their ability to recall experiences. Those adopted as infants or at very young 
ages. like Ardnt and Adolfson. often have little or no memory of Korea. compared with those adopted at later ages such as Borshay, at age eight. Despite losing her memory of Korea. Borshay describes. how in her twenties, she was haunted by images of Korea which punctured her consciousness. coming back to her at all hours of the daty. including the "ghost" of her dead father. Adolfson. on the other hand. adopted at age three, finds that his trip back to the city in which he wais born only verifies the fact that he has no memories of Korea. and he feels that he 11 "never really feel connected to this country."

21. In highlighting the similarities of these autoethnographies, I am not intending to elide the diversity of this grouping. Highly subjective and specific to each individual experience. they confound reductive summations of the work to any one aesthetic style or thematic trope.

22. The works discussed in this paper are produced by women directors, excepting Nathan Adolfison : Passing Throngh. Further study would be required to make any conclusions about the significance of gender in the production of these auto-ethnographies. For a discussion of the predominance of women among filmmakers of the Korean North American diaspora. see Lee (1998).

23. Naficy talks about his transnational cinema as a "structure of feeling" (Williams 1977). and in many ways the work in question could fall under that rubric. as it speaks to a kind of experience that is discursively uncertain. emergent. and not yet fully elaborated. Nevertheless. I am still cautious about ascribing a distinctive style to these works. No doubt, their common experiences as adoptees and as artists within specific milieux and the material constraints on their work has set the limits of the form.

24. This is certainly the case with Deann Borshay"s film. which traveled the festival circuits, and aired on national public television in December 2000). With PBS. she has organized local screenings and discussion groups for adoptees. produced an accompanying study guide for adoptees, adoption professionals, and adoptive parents available online through the PBS Web site. 25. The work of these filmmakers needs also to be considered in the context of the Asian American film movement, an outgrowth of the countercultural movements of the 1960) and 1970). This work can be regarded as part of the project of Asian American cultural activism which sechs to intervene in dominant stereotypes of Asian Americans and to give voice 6 alternative versions of history and subjectivity ree the films of artist-activists such as Loni Ding. (Christine Choy. Spencer Nakalsako, Rea Tajiri), though more research would be necessary to see how the work is being incorporated into sites of Asian American filmmaking (see Hamamoto 1994 and Xing 1998). Deann Borshay is well-positioned in this field. having been executive director of the prime funding institution for Asian American documentary. the National Asian American Television Asrociation (NAATA).

26. Transnational adoptees present a challenge to categories like diaspora and hy bridity. Typesof diaspora often discussed. such as exile. migrant. immigrant. and refugece fail to encompass the transnational adoptee experience. As children. ranging from infants to early teens, these adoptees had little or none of the agency las a form of rational decision-making. even if under extreme duress) that those categories presume.

27. Here l find Marks's periodization more useful than her deploying of new monikers and genrification of experimental film practice by people of color in the West. At the same time. however. her discussion of memory and embodied knowledge is very fitting with the work of Theiler and Ahn.

28. Like Maira (1999). I would argue that the valorization of hybridity in recent theoretical discourses obscures the actual processes of self-negotiation among indiviluals "hetween" cultures: "Social actors are able to draw on models of personhood that are based un stability and authenticity of cultural elements in some situations and to embrace identities that emphasize fluidity and multiplicity at other moments" (.5.3).

29. Tomes"s video was produced through an artist-inresidency grant at the Banff Center for the Arts and screened on Philadelphia public television. as well as at Ahn's "Evenstill" festival.

30. The program catalog for the Gathering, the first major conference for adult adoptess in September 1999. published the "before" and "after" photos of the f()() participants, along with the Korean name. date of birth. name of adoption agency, date of arrival, their home town (in the U.S. or Europe) and current profersion. For the SNAPSHOT exhibit, the Korean American Museum commissioned a monumental photographic quilt from adoptee artist Susan Sponsler who composed it out of "before" and "after" photos recerived 
from adoptees around the world.

31. Great Girl was produced through a Film/Video Arts artist-mentor program. and funded by the New York Foundation for the Arts. It has sereened in numerous short film festivals, as well as at "Evenstill." the SNAPSHOT exhibit, and at the KAAN festival in 1999. 32. Newspaper and television reporters in Korea are a main source of information and assistance for adoptees (see Crossing Chasms and Passing Through). The reporters can help the adoptees who are often unable to navigate the bureaucratic channels due to language barriers. Newspapers run advertisements detailing available information on the biological family or background events, and television news programs show brief clips of adoptees on their search. It seems to be a mutually beneficial arrangement. for if the reporter can find the adoptee's biological family. they ve clinched a story. as shown in Adolfson's film. Even though Koreans. stereotypically xenophobic, are reported to discriminate against Korean adoptees, reunion stories make good copy. Reunions of families separated during the Korean war was a huge televisual spectacle with the Korean Broadcasting Service's 198.3 telethon. There seems to be an analogous situation regarding the role of the media in facilitating adoptees" search and reunion to the phenomenon of the 1980)s which reunited orer 10.000 families separated for thirty years or more following the war (see Kim 1988).

33. For a compelling close reading of Theiler's filmtext. see Kang (1998).

34. living in halftones has been screened at film and video festivals in the U.S., Canada and Korea. Ahn won the Best Director's Award at the Center for Korean American Culture Film Festival in 1998.

35. Long Duck Dong is the 198()s version of the "Chinky-Chinaman." an offensive and über-racist depiction of an Asian "gcek" in the wildly popular teen film Siveen Candles (John Hughes 1986). With thick glasses and an accent. he represents the worst of antiAsian stereotypes. Other adoptees have talked about the lack of positive Asian role models during their childhoods as hav ing contributed to their exclusive identification with white American culture. As one adoptee at a conference put it. "We were Anthony Michael Hall in that movic: we weren't Long Duck Dong... when our parents were pushing culture on us, that was making us into Long Duck Dong."

36. SoYun Roe' USC Visual Anthropology Master's film Basilio's Family (1994) is also an interrogation of the familial gaze. composed of interviews with her adoptee-husband's Swiss family. Not an adoptee herself. Roe is actively involved in raising awareness about adoptees within the Korean American community in Los Angeles.

37. Deann Borshay Liem`s First Person Plural (2000) was nationally broadcast on December 18.2000 as part of P.O.V. The American Experience. PBS's showcase for new documentary work. In 1992 Borshay took leave from her position as the executive director of the National Asian American Television Association (NAATA) to devote herself to producing this. her first. film. As a work-in-progress, it was shown as part of an exhibit of Korean adoptee experience at the Korean American Museum in Los Angeles. It officially premiered at the Sundance Film Festival (2000) and was also showcased at NAATA: Asian American Film Festival in San Francisco in March 2000, at four soldout screenings. It also screened at "docfest" in 2000 . 38. Adolfson"s trajectory is a film school success story: against his parents" wishes he went to film school and produced this video which garnered him multiple awards. including a NAATA Finishing Grant. a Motion Picture Association of A merica Fellowship. a Director's Guild Award, and three awards from UCLA's film school. Passing Through aired on PBS in 2000 and has been screened at many adoptee conferences and events of the past year.

39. In an interview with Korean Quarterly (a Minnesota-based Korean American journal edited by an adoptive mother to two Korean children. which often features articles on Korean adoptee issues). Adolfsion is more candid about his parents and his anger: "Neither of them ever went to college. They've grown up and lived in the Anoka-Coon Rapids area their entire lives. and then adopted this child from this different world. And I think they were very misinformed. That was a lot of my problem. that 1 didn 't feel it was right that they put me in this situation. And that's why when I went to California. I fled" (Vickery 2000): 47).

4). The Yonsei Program. which Jennifer Arndt also enrolled in. is by now a kind of institutionalized rite of passage for Korean Americans in their high school and carly college years. Often the first time that many of them go to Korea without parental supervision. it is a way that many Korean Americans begin to develop an independent relationship to Korean society and culture. 
41. In this sequence Adolfson describes the Korcan student demonstrators, in a subtly self-reflexive. autocritical way: "The irony is, is that most of these students are from wealthy families, families who are part of the system' that they are trying to change, but that they have benefited from their entire lives. "He then turns the camera on himself. Adolfson s own struggle to distance himself from his parents. and to go to Korea likewise might be seen as a rebellion against the "system" from which he has benefited. Other adoptees have described the tension they feel between their own desire to search or find out about Korea. which some feel could be interpreted as disloyalty to their adoptive families.

42. Adolfson is reunited with his siblings with the help of Korean television, and their first meeting takes place on the sidewalk outside of a department store in Seoul. He cleverly juxtaposes his own video footage of the meeting with the heavily melodramatized footage from Korean TV. including the talk show he and his sister appeared on.

43. Ardnt suse of family photos is different. and she has a less conflicted relationship to her adoptive family. judging from Crossing. Chasm. Family snap shots in her video serve to underscore the "naturalness" of being an adopted child in a white family. Arndt"s parents seem to have been more involved with and informed about adoption and Korea, having been invited to go to Korea as "friendship ambassadors" by President Jimmy Carter. Ardnt also grew up with another Korean girl who her parents adopted shortly after adopting her. Many Korean adoptees who were adopted in sibling groups or with other Korean adoptees as adoptive siblings, advocate this arrangement, because it ameliorates the alienation of being adopted and of being an ethnic minority. 44. Borshay and Adolfson show family photos of their biological families. which index their own absence'. The photos of the Korean family stand in marked contradistinction from those of the adoptive family: the style of portraiture in Korea is much more formal and stoic. and contrasts sharply with the candid and studio photos of their white American families, in which the subjects are invariably smiling for the camera.

4.5. Borshay : film ends with snapshots of her oun family, her husband and her son. as well as with video footage of her mother-in-law. her son. and herself having Thanksgiving dinner at the Borshay"s.

46. Thanks to Hollee McGinnis for sharing this with me.
47. Statistics by Evan B. Donaldoon. an adoption research organization. show that 6 out of 10 people surveyed had experienced adoption in their oun families.

48. In the past year. a number of television commercials for major American corporations have presented positive depictions of adoptive families to a broad national viewership. JC Penney launched its pro-adoption ad during the Grammy's, and a controversial spot John Hancock aired during the 2000 Summer Olympics.

49 Legal anthropologist Barbara Yngvesson (1997) has explored the complex emotional and social negotiation of participating in an open adoption. Her article demonstrates the till considerable power of what Ginsburg (1989) calls "the expressive 'natural core" of mother and child, the ultinate symbol of nurturance and affect in American society" (242). The ideological potency of this "core" makes it difficult for all members of the adoption triad-birth mother/parents. adoptive mother/ parents and child- - o reconcile the co-existence of two mothers in the life of one person. Yngvesson describes the difficulty of negotiating her role as an adoptive mother vis-a-vis the birth mother in a social context which lacks models for these kinds of kinship arrangements.

50. At a recent conference for Korean adult adoptees. much was made of korean adoptee women "s "genetic" attributes: their distinctive hair. eyes, and calves. A peculiar, yet telling. anecdote show how. for isolated adoptees who are just beginning toconverse with others like them. the desire to ancribe individual behavioral or physical characteristics to an essential "Koreanness" can lead to the construction of new ethnicized categories. At a regional adoptee meeting following this conference. adoptces and their partners shared common experiences with what they coined "the freeze." a gendered ethnic/genetic trait purportedly shared by Korean women who "freeze" out their partners when they are angry.

51. Sie Roe (1994) on the "superextended families" of Korean adoptees. Reilly (2()(0)) gives a personal account of the reunion between his adopted daughter with her Korean birthmother, and Tyre (1999) describes a dramatic story of an adopted Korean boy heing "returned" to his father in koreat.

52. Adult adoptees are being looked to an "experts" of their own experiences by adoption agencies. These adoptees. some of whom are social workers them- 
selves, are asked to speak to prospective and adoptive parents about the identity issues and psychological problems they may expect to encounter as their transracially adopted children mature. Borshay explicitly targeted adoption professionals and parents as an audience for her film. wanting it to be a teaching aid and awareness-raising tool. and its effect on the first audience of adoptive parents was extraordinarily powerful: At the 2()() KAAN Conference, an audience of about 150 participants. almost all parents to adopted Korean children. were so moved to tears that boxes of tissues were put into circulation around the room.

\section{RFFFRINCr.s}

Alstein. Howard and Rita Simon. (eds.)

1991 Intercountry Adoption: A Multinational Perspective. New York: The Free Press.

Ando, Me-K

1994 Between Two Worlds. Women Working in Film and Video 2 (4): 23.

Appadurai. Arjun

1996 Modernity at Large: Cultural Dimensions of Globalization. Minneapolis: University of Minnesoti.

Bordowitz. Greg

1996 Operative Assumptions. In Resolutions: Contemporary Video Practices. Michael Renov, and Erika Suderburg. eds. Minneapolis: University of Minnesota.

Bourdieu. Pierre

199.3 The Field of Cultural Production. New York: Columbia University Press.

1998 Practical Reason: On the Theory of Action. Palo Alto: Stanford University Press.

Carp. E. Wayne

1998 Family Matters: Secrecy and Disclosure in the History of Adoption. Cambridge: Harvard.

Evan B. Donaldson Adoption Institute

1999a Annual Report. New York: Evan B. Donaldson Adoption Institute.

1999b Survey of Adult Korean Adoptees: Report on the Findings. Neew York: Evan B. Donaldson Adoption Institute.

Fischer, Michael

1986 Ethnicity and the Post-Modern Arts of Memory. In Writing Culture: The Poetics and Politics of
Ethnography. J. Clifford and G. Marcus, eds. Berkeley: University of California Press.

Fraser. Nancy

1992 Rethinking the Public Sphere: A Contribution to the Critique of Actually Existing Democracy. In Habermas and the Public Sphere. Calhoun, ed. Cambridge: MIT Press.

Ginsburg. Faye

1989 Contested Lives: The Abortion Debate in an American Community. Berkeley: University of California Press.

1991 Indigenous Media: Faustian Contract or Global

Village? Cultural Anthropology 6(1): 92-111.

Gupta. Akhil and James Ferguson

1992 Beyond 'Culture: Space. Identity and the Politics

of Difference. Cultural Anthropology 7(1): 6-23.

Hamamoto. Darrell Y.

1994 Monitored Peril: Asian Americans and the Poli-

tics of TV Representation. Minneapolis: University of Minnesota.

Herrmann, Kenneth J. Jr. and Barbara Kalsper

1992 International Adoption: The Exploitation of

Women and Children. Affilia 7(1): 45-58.

Hirsch. Marianne

1997 Family Frames: Photography. Narrative. and

Postmemory. Cambridge: Harvard University Press. Juhasz. Alexandra

199.5 AIDS TV: Identity. Community and Alternative

Video. Durham. NC: Duke University.

Kang. Hyun Yi

1998 Re-membering Home. In Dangerous Women:

Gender and Korean Nationalism. Elaine Kim and

Chungmoo Choi. eds. New York: Routledge.

Kane. Saralee

1993 The Movement of Children for International

Adoption: An Epidemiologic Perspective. The

Social Science Journal 3()(4): 323-339.

Kim. Chang-ki

1999 Foreign Adoption on the Increase. Chosun Ilbo.

January 11.

Kim. Choong Soon

1988 Faithful Endurance: An Ethnography of Korean

Family Dispersial. Tuscon: University of Arizona.

Kim. Yeon-kwang

2000 Adoption Restrictions to be Removed. Chosun llbo. March 7.

Korea Times

2(10) Korean Children Adopted by Foreigners on 
Increase. May 4.

Korean Quarterly

1999 A Half Century of Koreans In Minnesota-a

Timeline. Winter: 35.

Lee. Helen

1998 A Peculiar Sensation: A Personal Genealogy of

Korean American Women's Cinema. In Dangerous Women: Gender and Korean Nationalism. Elaine Kim and Chungmoo Choi. eds. New York: Routledge.

Lieberthal. Meg

1999 Connecting with the Past: Commemorating the

Korean War. Transcultured 2(1): 19.

Maira. Sunaina

1999 Identity Dub: The Paradoxes of an Indian American Youth Subculture (New York Mix). Cultural Anthropology 14(1): 29-60.

Marks. Laura U.

2000 Skin of the Film: Intercultural Cinema. Embodiment. and the Senses. Durham: Duke University. McGinnis Hollee. Joy Lieberthal and Thomas Park Clement

1999 Our Past: From the Ashes of War New Lives Were

Born. Transcultured 1(4): 2-4.

McGinnis. Hollee

1999 "Letter from the Editor" Transcultured 1(4).

Modell. Judith

1999 Freely Given: Open Adoption and the Rhetoric of the Gift. In Transformative Motherhood: On Giving and Getting in a Consumer Culture. Linda L. Layne. ed. New York: NYU Press.

1994 Kinship with Strangers. Berkeley: University of California Press.

Modell. Judith and John Terrell

1994 Anthropology and Adoption. American Anthopologist 16(1): 155-161.

Naficy, Hamid

1997 The Accented Style of the Independent Transnational Cinema: A Conversation with Atom Egoyan. In Cultural Producers in Perilous States. George Marcus, ed. Chicago: Liniversity of Chicago.

Park, Ty

1999 Cry Korea Cry. New York: The Wordhouse.

Park. Yoon-bae

2000 New Approach Needed on Foreign Adoption. Korea Times. March 10.
Peletz Michael G.

1995 Kinship Studies in Late Twenticth - Century Anthropology. Annual Review of Anthropology 24:34.3-72.

Reese. Carol Olwert

1997 Media Presentation of 'Search.' 'Reunion' and

Open Records. Adoption Quarterly 1(2): 101-110 Reilly. Rick

2000 Seoul Searching. Time 15619). August 28.

Renov. Michael

1995 New Subjectivities: Documentary and Self-Representation in the Post-Verité Age. Documentary Box 7. Yamagata International Documentary Film Festival.

Roe. SoYun

1994 My Husband 's Families: Kinship in an International Korean Adoptive Superextended Family. m.s. M.A. Thesis, USC Visual Anthropology Department.

1999 Introduction. SNAPSHOT Exhibit. Korean American Museum. Los Angeles.

Russell. Catherine

1999 Experimental Ethnography: The Work of Film in the Age of Video. Durham: Duke University.

Sarri. R.C.. Y. Baik and M. Bombyk

1998 Goal Displacement and Dependency in South Korean-United States Intercountry Adoption. Children and Youth Services Review. 20)(1/2): 87-114 Schein. I.ouisa

2()()) Mapping Hmong Media in Diasporic Space. Forthcoming in The Social Practices of Media. Ginsburg. Abu-Lughod. Larkin. eds.

Schneider. David

1968 American Kinship: A Cultural Account. Chicatgo: University of Chicago.

1984 A Critique of the Study of Kinship. Ann Arbor: Iniversity of Michigan.

Shin. Hyeson

1999a Center for Returning Adoptees Opens in Seoul. Korea Herald. July 2.

1999b IMF Economic Pinch Increases Number of Abandoned Children. Korea Herald. August 16.

Soh. Ji-young

26(x) Domestic Adoptions Growing. Korea Times August 6.

Stock. Kimberly K! ung Hee

1999 Rice of a Fourth Culture: Korean Adoptees.

Transcultured 1(4): 11 . 
1999 New Visa Law Still Open to Adjustments for

Overseas Korean Adoptees. Korea Herald. December 7 .

Tomlinson. John

1996 Global Experience as a Consequence of Modernity. In Globalization. Communication and Transnational Civil Society. Braman and SrebernyMohammadi. eds. Cresskill. NJ: Hampton Press.

Tyre. Peg

1999 We Galve Him Up to Save His Life. New York

Magazine. March 1.

Vickery. Martha

20)() A Rite of Passage Recorded: Nathan Adolfson and Passing Through. Korean Quarterly. Spring: $46-47$.

Wilggenspack. Beth $M$.

1998 The Symbolic Crises of Adoption: Popular Media ${ }^{\circ}$ Agenda Setting. Adoption Quarterly 1(4): 57-82.

Wegar. Katrina

1997 Adoption. Identity, and Kinship: The Debate Over Sealed Birth Records. New Haven: Yale University.

1998 Adoption and Kinship. In Families in the U.S.:

Kinship and Domestic Politics. K. Hansen and A.

Garey. eds. Philadelphia: Temple University.

Weston. Kathleen

1991 Families We Choose: Lesbians. Gays. Kinship.

New York: Columbia University.

Williams. Raymond

1977 Marxism and Literature. Oxford: Oxford University Press.

Xing. Jun

1998 Asian America Through the Lens: History. Representations, and Identity. Walnut Creek. CA: AltaMira Press.

Yngvesson. Barbara

1997 Negotiating Motherhood: Identity and Difference in "Open" Adoptions. Law and Society Review. $31(1): 31-80$.

Zimmerman. Patricia

1995 Reel Families: A Social History of Amateur Film.

Bloomington: Indiana Liniversity Press.
Adolfson. Nathan

1999 Passing Through. Video. NAATA. $27 \mathrm{~min}$.

Ahn. Me-K. (Karen Me Kyung Muckenhirn)

1994 living in halftones. Video. Third World Newsreel. 9 min.

1996 Undertow. $16 \mathrm{~mm}$. Third World Newsreel. 18 $\min$.

Arndt. Jennifer Christine Yang Hee

1998 Crossing Chasms. Video. Rainbow World. 58 $\min$.

Borshay Liem. Deann

2000 First Person Plural. Video. NAATA. $57 \mathrm{~min}$.

Jang, Gil-soo

1991 Susan Brink's Arirang. Korea.

Koh, Jay

2000 True. $16 \mathrm{~mm}$. $1 \mathrm{hr} .30 \mathrm{~min}$.

Roe. SoYun

1994 Basilio : Family. Video. University of Southern California. $53 \mathrm{~min}$.

Tajiri. Rea

1991 History and Memory (for Akiko and Takeshige) Video and $8 \mathrm{~mm}$. Electronic Arts Intermix. $32 \mathrm{~min}$.

Theiler. Kim Su

1993 Great Girl. 16 mm. Women Make Movies. 14 $\min$.

Tolle. Tammy (Chu Dong Soo)

1998 Searching for Go-Hyang. Video and $16 \mathrm{~mm}$. Women Make Movies. $31 \mathrm{~min}$.

Tomes, Kimberly SaRee

1997 Looking for Wendy. Video and 16mm. Third World Newsreel. $18 \mathrm{~min}$. 